\title{
A família Leguminosae Juss. em dois afloramentos rochosos no município de Puxinanã, Paraíba
}

\author{
Sebastiana Angelita Lima da Silva \\ José Iranildo Miranda de Melo * \\ Universidade Estadual da Paraíba, Centro de Ciências Biológicas e da Saúde \\ Departamento de Biologia, CEP 58429-500, Campina Grande - PB, Brasil \\ * Autor para correspondência \\ tournefort@gmail.com
}

Submetido em 02/11/2012

Aceito para publicação em 17/07/2013

\section{Resumo}

Este artigo reporta o levantamento taxonômico de Leguminosae Juss. em dois afloramentos rochosos no município de Puxinanã, Paraíba, Brasil. Foram registradas 29 espécies e 17 gêneros, distribuídos nas seguintes subfamílias: Caesalpinioideae ( 9 espécies, 5 gêneros), Mimosoideae (10 espécies, 4 gêneros) e Papilionoideae (10 espécies, 8 gêneros). O hábito arbustivo foi observado com maior frequência, englobando 48\% das espécies. São apresentadas chaves para a identificação de subfamílias e respectivas espécies, descrições, comentários e dados sobre a distribuição geográfica das espécies.

Palavras-chave: Afloramentos rochosos; Brasil; Fabaceae; Florística

\section{Abstract}

The family Leguminosae Juss. on two rocky outcrops in the town of Puxinanã, Paraiba, Brazil. This paper reports the taxonomic survey of Leguminosae Juss. on two rocky outcrops in the town of Puxinanã, Paraiba, Brazil. We recorded a total of 29 species and 17 genera, distributed into the following subfamilies: Caesalpinioideae ( 9 species, 5 genera), Mimosoideae (10 species, 4 genera), and Papilionoideae (10 species, 8 genera). The shrubby habit was observed more frequently, comprising $48 \%$ of species. Keys are provided for identifying subfamilies and their respective species, descriptions, comments, and data on the geographic distribution of species.

Key words: Brazil; Fabaceae; Floristics; Rocky outcrops 


\section{Introdução}

A família Leguminosae Juss. ou Fabaceae Lindl. (sensu APG II, 2003) está formalmente dividida em três subfamílias: Caesalpinioideae, Mimosoideae e Papilionoideae (JUDD et al., 1999). Suas espécies apresentam hábitos muito variados, desde grandes árvores, arbustos, ervas e trepadeiras, tanto escandentes como volúveis, encontradas em diferentes ambientes (FERREIRA et al., 2004). Quase sempre apresentam folhas compostas; filotaxia alterna e estípulas (FERREIRA et al., 2004), nectários extraflorais podem estar presentes no pecíolo e/ou na raque. Um aspecto importante do hábito das leguminosas da Caatinga diz respeito ao armamento dos ramos. Muitas espécies são inermes, mas é comum encontrar espécies armadas com espinhos ou acúleos (QUEIROZ, 2009).

A Caatinga é o principal ecossistema existente na região Nordeste do Brasil, estendendo-se pelo domínio do Semiárido (MARACAJÁ et al., 2003). A Caatinga possui grande variedade de paisagens, considerável riqueza biológica e endemismos e famílias como Leguminosae, Euphorbiaceae, Bignoniaceae e Cactaceae são muito importantes por representarem a maior parte da diversidade florística da região (CARDOSO; QUEIROZ, 2007). Dentre estas, Leguminosae é a mais diversa, com 77 gêneros e 293 espécies, das quais 144 são endêmicas (CARDOSO; QUEIROZ, 2007).

Leguminosae é a terceira maior família de angiospermas, compreendendo cerca de 727 gêneros e 19.325 espécies (LEWIS et al., 2005). Possui grande importância econômica, o que a torna uma família muito conhecida. Numerosas espécies são utilizadas como alimento, forragens, corantes, madeiras, gomas, resinas, óleos, medicinais e ainda como ornamentais (FRANCINO, 2006).

O município de Puxinanã se destaca por apresentar uma série de afloramentos rochosos cobertos por vegetação arbustivo-herbácea, por vezes arbustivoarbórea. O estudo dos ambientes rochosos em diferentes localidades da região tropical tem revelado várias similaridades e dissimilaridades ambientais, em especial aquelas relacionadas às condições edáficas e microclimáticas, decorrentes das diferenças no estágio de fragmentação das rochas (POREMBSKI et al., 1998). Apesar de sua ampla ocorrência na região Nordeste do Brasil, poucos estudos têm sido desenvolvidos nesses ecossistemas (ALMEIDA et al., 2007).

Este trabalho consiste do levantamento florísticotaxonômico de Leguminosae Juss. em dois afloramentos rochosos no município de Puxinanã, mesorregião Agreste, Estado da Paraíba, Brasil. Tem o intuito de contribuir para o conhecimento da flora local e, sobremaneira, da família Leguminosae nessas formações, fornecer chaves de identificação para subfamílias, gêneros e espécies, descrições e dados de distribuição geográfica.

\section{Material e Métodos}

\section{Área de estudo}

$\mathrm{O}$ estudo foi desenvolvido em dois afloramentos rochosos situados no entorno do espaço urbano do município de Puxinanã (0708'55,1'S, 35 57'54,2”W - 07008'31,0”S, 3558'07,2”W), Paraíba (Figura 1; $3 \mathrm{~A} ; 3 \mathrm{~B})$.

FIGURA 1: Vista frontal dos afloramentos I e II, respectivamente.

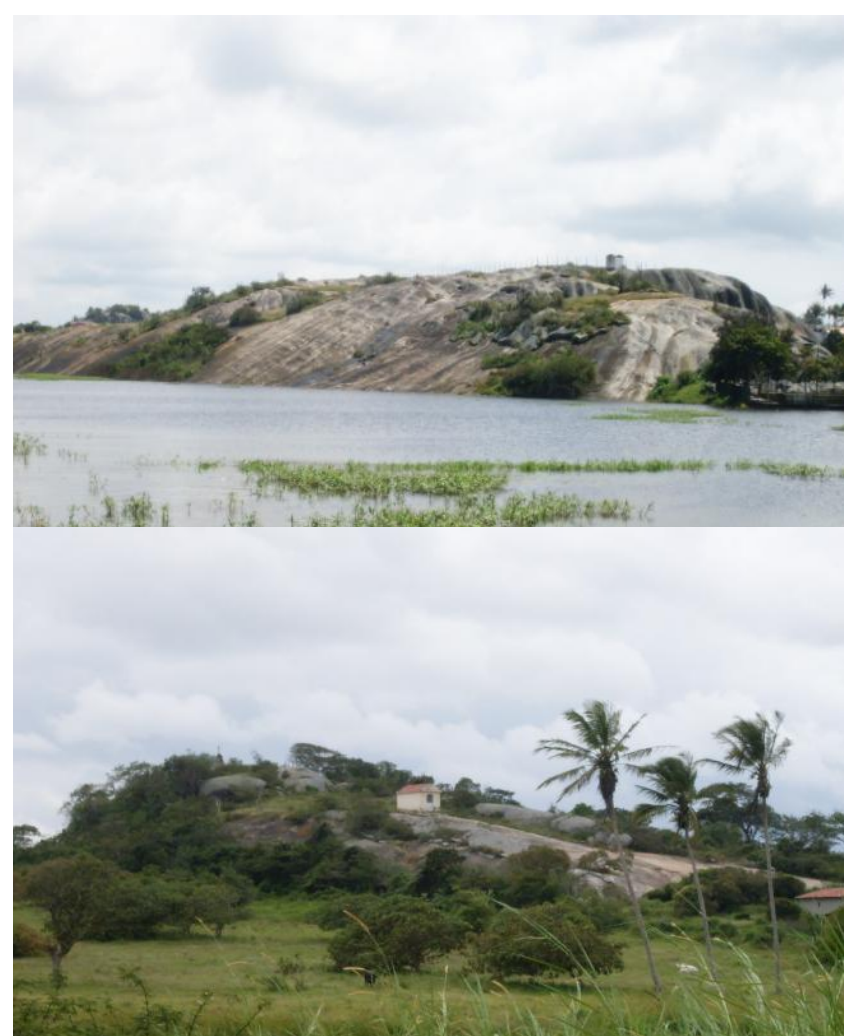


Este município destaca-se por apresentar um expressivo conjunto de afloramentos rochosos de grande porte, localizados tanto na área urbana, quanto no espaço rural. Apresenta ainda uma considerável altitude, variando entre 650 e 1000 m, e uma vegetação formada por florestas Subcaducifólia e Caducifólia, próprias das áreas localizadas no agreste (MME, 2005).

O município de Puxinanã situa-se na zona fisiográfica "Borborema Central" (RIBEIRO et al., 2008), num dos pontos mais altos do Estado da Paraíba (RIBEIRO; TEOTIA, 2007), na Mesorregião do Agreste e Microrregião de Campina Grande, Leste do estado da Paraíba. Possui uma área de $74 \mathrm{~km}^{2}$, representando 0,13\% do Estado (BRASIL, 2005) e está inserida na unidade geoambiental do Planalto da Borborema.

Apresenta uma paisagem característica (MARACAJÁ et al., 2006) e sua vegetação é formada por florestas subcaducifólias e caducifólias (BRASIL, 2005). Por estar inserido no Agreste paraibano, Puxinanã se caracteriza como uma área de transição entre a zona da mata e a zona das caatingas interioranas (TÖLKE et al., 2011), apresentando um clima tropical com estação chuvosa iniciando entre os meses de janeiro/março e terminando entre os meses de julho/agosto, com índices de precipitação pluviométrica entre $300 \mathrm{~mm}$ e 1800 $\mathrm{mm} / \mathrm{ano}$, com temperatura máxima registrada de $28^{\circ} \mathrm{C}$ e mínima de $16^{\circ} \mathrm{C}$ (AESA, 2006).

Intitulada por alguns como a cidade dos lajedos (MARACAJÁ et al., 2006), tem sua história ligada aos seus afloramentos rochosos e a uma lagoa localizada no centro da cidade. Grande parte dos seus afloramentos possui uma cobertura vegetal bastante diversificada e embora seja reconhecido o seu potencial ecológico, a área é pouco conhecida em relação aos aspectos florísticos.

\section{Procedimentos de campo e de laboratório}

Foram realizadas coletas quinzenais por toda extensão dos afloramentos, através de caminhadas aleatórias no período compreendido entre agosto de 2010 a agosto de 2011. Durante as coletas foram tomadas anotações relevantes sobre o ambiente e as espécies, e obtidas amostras de indivíduos incluindo todas as formas de vida (herbácea, arbustiva, trepadeira e arbórea) de Leguminosae encontradas nos afloramentos estudados.

As amostras foram prensadas, herborizadas e incorporadas à coleção do Herbário Manuel de Arruda Câmara (ACAM) da Universidade Estadual da Paraíba (UEPB), Campus I, Campina Grande, Paraíba.

As identificações foram realizadas com base em literatura especializada (CÓRDULA et al., 2009; QUEIROZ, 2009). A elaboração da lista de espécies foi feita com base no APG II (2003). Os nomes dos autores de subfamílias, gêneros e espécies foram consultados na Lista de Espécies da Flora do Brasil (FORZZA et al., 2011), na base de dados do International Plant Names Index (IPNI, 2012), bem como do Missouri Botanical Garden (W ${ }^{3}$ TROPICOS, 2010) e na literatura sobre Leguminosae (VAZ; TOZZI, 2003; DAMBROS et al., 2004; RODRIGUES et al., 2005; PIRES et al., 2006; SILVA; SALES, 2008; SAVASSI-COUTINHO, 2009; BARROS, 2011).

As descrições foram baseadas na amplitude de variações morfológicas observadas no material coletado em Puxinanã e sempre que possível foram consultadas as descrições originais. Os dados foram compilados em uma tabela para a elaboração da chave de identificação. A distribuição geográfica restringe-se ao Brasil e foi obtida na Lista de Espécies da Flora do Brasil (FORZZA et al., 2011), sendo complementada pela literatura especializada.

\section{Resultados e Discussão}

A análise florístico-taxonômica de Leguminosae Juss. nos dois afloramentos rochosos estudados no município de Puxinanã, Paraíba, revelou a ocorrência de 29 espécies pertencentes a 17 gêneros e três subfamílias. Destas, nove espécies pertencem a Caesalpinioideae, seguidas de Mimosoideae e Papilionoideae com dez espécies cada (Tabela 1). 
TABELA 1: Checklist de Leguminosae Juss. em dois afloramentos rochosos no município de Puxinanã, PB, Brasil. Legenda: Subarb. $=$ Subarbusto; Arb. $=$ Arbusto; Arv. = Árvore; Trep. $=$ Trepadeira; Liana $=$ Liana $. \mathbf{A} \mathbf{1}=$ Afloramento $1 ; \mathbf{A 2}=$ Afloramento 2.

\begin{tabular}{|c|c|c|c|}
\hline SUBFAMÍLIA/ESPÉCIE & HÁBITO & A1 & A2 \\
\hline \multicolumn{4}{|l|}{ CAESALPINIOIDEAE } \\
\hline Bauhinia cheilantha (Bong.) Steud. & Arb. & & $\mathrm{X}$ \\
\hline Chamaecrista rotundifolia (Pers.) Greene & Erv. & $\mathrm{X}$ & \\
\hline Erythrostemon sp. & Arb. & & $\mathrm{X}$ \\
\hline Poincianella gardneriana (Benth.) L.P.Queiroz & Arv. & & $\mathrm{X}$ \\
\hline Senna martiana (Benth.) H.S.Irwin \& Barneby & Arb. & $\mathrm{X}$ & \\
\hline Senna obtusifolia (L.) H.S.Irwin \& Barneby & Subarb. & $\mathrm{X}$ & $\mathrm{X}$ \\
\hline Senna rizzinii H.S.Irwin \& Barneby & Subarb. & & $\mathrm{X}$ \\
\hline Senna splendida (Vogel) H.S.Irwin \& Barneby & Arb. & $\mathrm{X}$ & \\
\hline Senna sp. & Arb. & & $\mathrm{X}$ \\
\hline \multicolumn{4}{|l|}{ MIMOSOIDEAE } \\
\hline Chloroleucon dumosum (Benth.) G.P.Lewis & Arb. & $\mathrm{X}$ & \\
\hline Mimosa misera Benth. & Subarb. & & $\mathrm{X}$ \\
\hline Mimosa paraibana Barneby & Arb. & $\mathrm{X}$ & $\mathrm{X}$ \\
\hline Mimosa pigra $\mathrm{L}$. & Arb. & $\mathrm{X}$ & \\
\hline Mimosa sensitiva $\mathrm{L}$. & Subarb. & $\mathrm{X}$ & $\mathrm{X}$ \\
\hline Mimosa sp. & Arb. & $\mathrm{X}$ & \\
\hline Pithecellobium dulce Benth. & Arv. & & $\mathrm{X}$ \\
\hline Senegalia polyphylla (DC.) Britton \& Rose in Britton \& Killip & Arb. & & $\mathrm{X}$ \\
\hline Senegalia ricoae (Bocage \& Miotto) L.P.Queiroz & Arb. & & $\mathrm{X}$ \\
\hline Senegalia tenuifolia Britton \& Rose & Arb. & & $\mathrm{X}$ \\
\hline \multicolumn{4}{|l|}{ PAPILIONOIDEAE } \\
\hline Aeschynomene evenia $\mathrm{C}$. Wright & Subarb. & $\mathrm{X}$ & \\
\hline Calopogonium caeruleum (Benth.) Hemsl. & Trep. & & $\mathrm{X}$ \\
\hline Canavalia brasiliensis Mart. ex Benth. & Trep. & & $\mathrm{X}$ \\
\hline Crotalaria bahiensis Windler \& S.G.Skinner & Arb. & $\mathrm{X}$ & $\mathrm{X}$ \\
\hline Dioclea grandiflora Mart. ex Benth. & Liana & $\mathrm{X}$ & $\mathrm{X}$ \\
\hline Dioclea violacea Mart. ex Benth. & Liana & $\mathrm{X}$ & $\mathrm{X}$ \\
\hline Macroptilium bracteatum (Nees \& Mart.) Maréchal \& Baudet & Erva & $\mathrm{X}$ & \\
\hline Macroptilium lathyroides (L.) Urb. & Erva & $\mathrm{X}$ & \\
\hline Vigna peduncularis (Kunth) Fawc. \& Rendle & Trep. & $\mathrm{X}$ & $\mathrm{X}$ \\
\hline Zornia myriadena Benth. & Erva & $\mathrm{X}$ & $\mathrm{X}$ \\
\hline
\end{tabular}

Quanto ao hábito, o mais representativo foi o arbustivo, compreendendo $48 \%$ do total, representado por 14 espécies pertencentes a nove gêneros, seguido pelo hábito subarbustivo, com 14\%, incluindo quatro espécies pertencentes a três gêneros e, o herbáceo, perfazendo $14 \%$ com quatro espécies pertencentes a três gêneros. Entre as trepadeiras foram registradas três espécies em três gêneros, englobando $10 \%$ do total, duas espécies são lianas representando $7 \%$ e, duas apresentaram hábito arbóreo, correspondendo a 7\% do total de espécies (Figura 2). 
FIGURA 2: Percentual das espécies registradas em dois afloramentos rochosos no município de Puxinanã, PB, segundo o hábito.

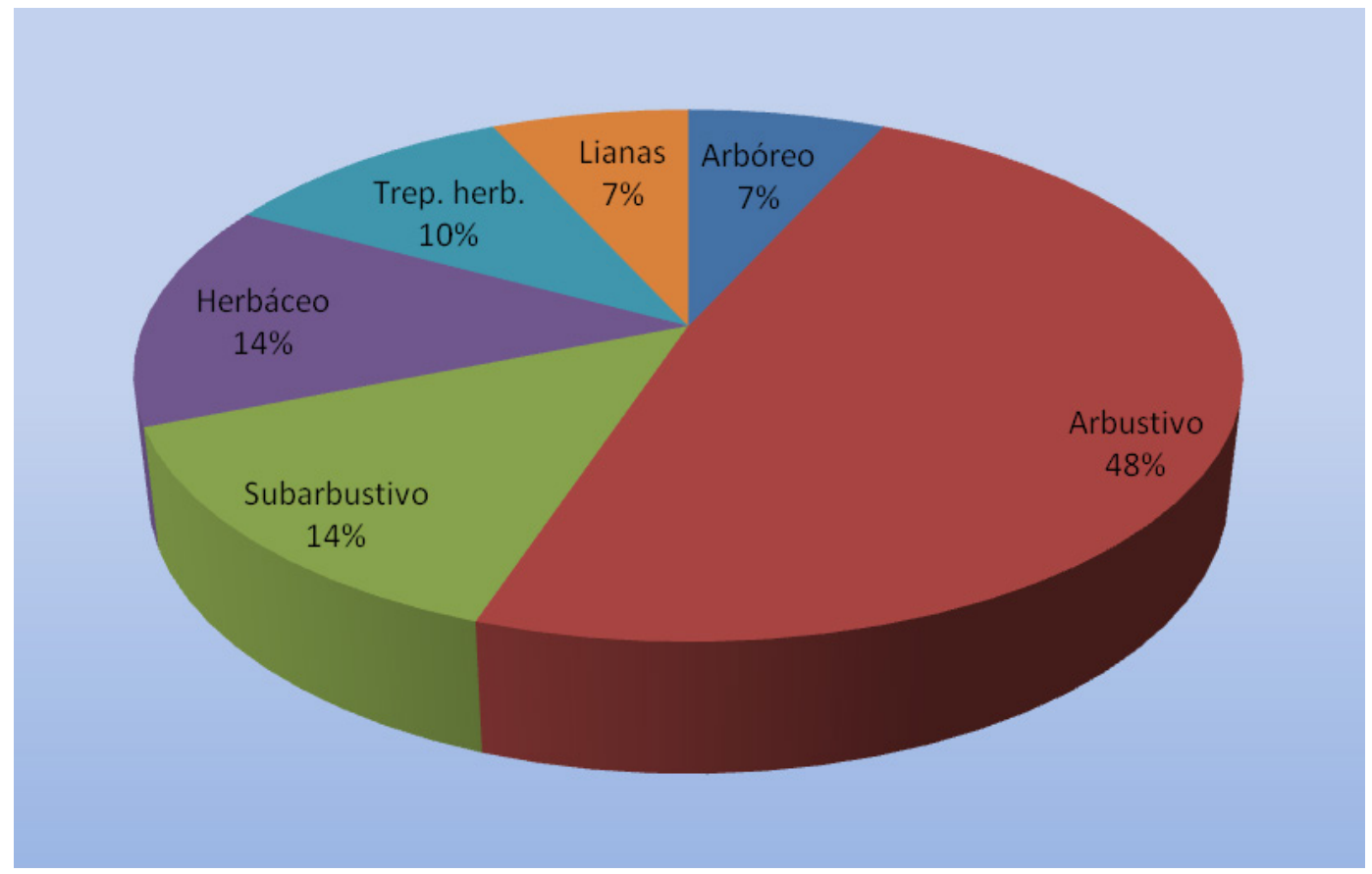

$\mathrm{Na}$ área de estudo sobressaíram-se as espécies Senna martiana (Benth.) H.S.Irwin \& Barneby, S. obtusifolia (L.) H.S.Irwin \& Barneby, Mimosa paraibana Barneby, Vigna peduncularis (Kunth) Fawc. \& Rendle e Zornia myriadena Benth., pela frequência de ocorrência. Das 29 espécies encontradas neste estudo, nove são endêmicas da Caatinga, representando 31\% do total registrado.

Considerando a flora de Leguminosae na Paraíba, nove espécies estão sendo referidas pela primeira vez para o Estado neste trabalho, são elas: Mimosa misera Benth., M. pigra L., M. sensitiva L. e Senegalia ricoae (Bocage \& S.T.S. Miotto) L. P. Queiroz (Mimosoideae); Aeschynomene evenia Wright, Crotalaria bahiensis Windler \& S.G. Skinner, Dioclea violacea Mart. ex Benth., Vigna peduncularis (Kunth) Fawc. \& Rendle e Zornia myriadena Benth. (Papilionoideae).

Nos afloramentos rochosos estudados, Caesalpinioideae está representada por oito espécies, onde Senna é o melhor representado com quatro espécies, seguido de Bauhinia L., Chamaecrista Moench, Erytrhostemon Link, Klotzschk \& Otto e Poincianella Britton \& Rose, com apenas uma espécie cada. Mimosoideae está representada por oito espécies, e Mimosa L. foi o gênero mais diversificado taxonomicamente, com cinco espécies, seguido por Senegalia Raf., com três espécies, e os gêneros Chrololeucon (Benth.) Britton \& Rose e Pithecellobium Mart. com apenas uma espécie cada. A subfamília Papilionoideae englobou dez espécies distribuídas em oito gêneros, e os gêneros mais representativos foram Dioclea Kunth e Macroptilium (Benth.) Urb., com duas espécies cada. Os demais gêneros encontram-se representados por uma espécie cada.

\section{Chave para as subfamílias de Leguminosae}

1. Inflorescências em espigas, glomérulos ou umbelas; flores actinomorfas, cálice e corola reduzidos, corola com pré-floração valvar; folhas geralmente bipinadas, às vezes pinadas ou reduzidas a filódios

Mimosoideae

1. Inflorescências em racemos ou panículas, flores zigomorfas, cálice e corola não reduzidos, constituindo um atrativo floral, corola com pré- 
floração imbricada; folhas pinadas ou bipinadas, digitadas ou trifolioladas

2. Pré-floração imbricada descendente; corola papilionoide, com pétalas diferenciadas em estandarte, alas e carena ............... Papilionoideae

2. Pré-floração imbricada ascendente; corola não papilionoide, com pétalas livres entre si

Caesalpinioideae

Chave para as espécies da subfamília Caesalpinioideae

1. Folhas simples com ápice bilobado

1. Bauhinia cheilantha

1. Folhas compostas

2. Folhas bipinadas; fruto plano

3. Folíolos alternos, +ou- romboides com base assimétrica 4. Poincianella gardneriana

3. Folíolos opostos, elípticos a oblongos com base simétrica

3. Erytrhostemon sp.

2. Folhas bifolioladas ou pinadas; fruto compresso, plano-compresso ou cilíndrico

4. Erva prostrada; ramos densamente híspidos; folhas bifolioladas

2. Chamaecrista rotundifolia

4. Arbustos ou subarbustos; ramos velutinos, vilosos ou glabros; folhas pinadas paripenadas

5. Folhas com 17-23 pares de folíolos, sem nectários 5. Senna martiana

5. Folhas com 2 ou 3 pares de folíolos e nectário presente no primeiro par de folíolos ou entre o primeiro e o segundo par

6. Folíolos em 3 pares, membranáceos, com nectários fusiformes localizados entre o primeiro e o segundo par de folíolos 6. Senna obtusifolia

6. Folíolos em 2 pares, coriáceos ou papiráceos, com nectário clavado ou pateliforme, localizado no primeiro par de folíolos

7. Nectário pateliforme; flores com ca. 1,5 cm diâm. 9. Senna sp.

7. Nectário clavado, curtamente estipitado; flores com ca. 3,5 a 7 cm diâm.

8. Folíolos assimétricos na base, pilosos a vilosos, de margem concolor 7. Senna rizzinii

8. Folíolos simétricos na base, glabros, de margem discolor 8. Senna splendida

1. Bauhinia cheilantha (Bong.) Steud., Nom. Bot. 2(1): 191. 1840.
Arbusto, 1,5-3,5 m alt.; ramos jovens densamente pubérulos, tricomas curtos e amarelados. Folhas simples com ápice bilobado, 6-14 x 6,2-13 cm, lâmina cartácea, suborbicular, lobos largamente arredondados, dividida no ápice por $1 / 3$ a $1 / 2$ do seu comprimento, base cordada; nervuras $11(-13)$, salientes na face abaxial, nervura secundárias salientes e levemente perpendiculares às primárias, face adaxial esparsamente pubérula, face abaxial tomentosa, tricomas glandulares esparsos. Inflorescências em pseudoracemos terminais, botões clavados, não estriados, retos. Flores 14-15 mm compr., com hipanto cilíndrico, sépalas lineares, 22 x 3,5 mm; pétalas brancas, ca. 45 × $20 \mathrm{~mm}$, obovais; ovário estipitado, tomentoso; 10 estames férteis, ca. $30 \mathrm{~mm}$ compr. Legume 11-13 x 1,5 cm, elasticamente deiscente, linear, estípite ca. 1,5 cm compr.; valvas pubérulas, lenhosas.

Material examinado: BRASIL: Paraíba: Puxinanã, Afloramento II, 24/X/2010, fr., S.A.L. Silva 01 (ACAM).

Distribuição geográfica: Nordeste (Maranhão, Piauí, Ceará, Rio Grande do Norte, Paraíba, Pernambuco, Bahia, Alagoas), Centro-Oeste (Mato Grosso, Mato Grosso do Sul), Sudeste (Minas Gerais) (VAZ, 2011). $\mathrm{Na}$ Caatinga, $B$. cheilantha ocorre principalmente em formações mais abertas, com ocorrência sobre solos pobres e pedregosos, em altitudes de 350 a $560 \mathrm{~m}$ (QUEIROZ, 2009).

Bauhinia cheilantha é facilmente reconhecida pelas folhas simples, bilobadas, diferenciando-se das demais espécies congêneres associadas à Caatinga por apresentar pétalas largas e obovais.

2. Chamaecrista rotundifolia (Pers.) Greene, Pittonia 4: 31.1899.

Figura 3C

Erva prostrada ou subarbusto escandente; ramos inermes, densamente híspidos. Folhas bifoliadas, alternas e glabras; estípulas peltadas, ovais a lanceoladas, 6-12 x 2,5-4 mm; pecíolo 3-6 mm compr.; glândulas pateliformes na base do folíolo (superior maior e inferior menor). Flores com dimensões variáveis; botões ovoides, deflexos e acuminados; sépalas oval- lanceoladas, ligeiramente equilongas; pétalas obovais, cuculo pouco 
diferenciado, amarelas; pedicelo supra-axilar, isolado, $3 \mathrm{~cm}$ compr. Legume 3,5-4 x 0,4-0,6 cm, linear, planocompresso, valvas papiráceas, esparsamente pubérulas.

Material examinado: BRASIL: Paraíba: Puxinanã, Afloramento I, 22/VII/2011, fl., fr., S.A.L. Silva 02 (ACAM).

Distribuição geográfica: Norte (Tocantins, Rondônia), Nordeste (Maranhão, Piauí, Ceará, Rio Grande do Norte, Paraíba, Pernambuco, Bahia), CentroOeste (Mato Grosso, Goiás, Distrito Federal, Mato Grosso do Sul), Sudeste (Minas Gerais, Espírito Santo, São Paulo, Rio de Janeiro), Sul (Paraná, Rio Grande do Sul) (SOUZA; BORTOLUZZI, 2011a). Ocorre na Caatinga como planta pioneira em hábitats degradados, entre 400-600 m alt. (QUEIROZ, 2009).

Chamaecrista rotundifolia caracteriza-se, principalmente, pelas flores com dimensões variáveis, podendo ser relativamente pequenas, 5-7 $\mathrm{mm}$ diâm., ou maiores, com 13-18 mm diâm., com androceu pentâmero e dois estaminódios.

\section{Erythrostemon sp.}

Árvore a arbusto; ramos inermes. Folhas bipinadas, folíolos opostos na raque da pina, elípticos a oblongos com base simétrica. Inflorescências em racemos terminais ou axilares. Flores zigomorfas com pétalas amarelas. Legume deiscente, plano, compresso, oblongo.

Material examinado: BRASIL: Paraíba: Puxinanã, Afloramento II, 27/II/2011, fl., fr., S.A.L. Silva 03 (ACAM).

Segundo Queiroz (2009), o gênero inclui 12-13 espécies com distribuição restrita às Américas, a maioria na América do Sul e apenas uma espécie está registrada na Caatinga.

Esta espécie pode ser facilmente reconhecida por apresentar folíolos opostos, elípticos a oblongos, de base simétrica.

4. Poincianella gardneriana (Benth.) L.P.Queiroz, Legum. Caatinga: 123. 2009.

Arvoreta ou arbusto, 3 a $8 \mathrm{~m}$ alt.; ramos inermes, tronco 15-25 cm diâm., acinzentado; indumento dos ramos jovens, eixos foliares e eixos da inflorescência esparsamente pubérulos até glabros. Folíolos alternos, 6-10 (+ pina terminal) pinas subopostas, 3,5-7 cm compr., coriáceos, distantes entre si 10-17 mm compr., acrescentes distalmente, os medianos 14-27 x 11-22 mm, mais longos do que largos, suborbiculares, ápice obtuso a arredondado, base assimétrica, esparsa a densamente pubérula em ambas as faces; nervura principal oblíqua a excêntrica na base, juntamente com as nervuras secundárias e as terciárias reticuladas, salientes em ambas as faces ou apenas na face abaxial; estípulas não vistas; pecíolo 18-23 mm compr.; raque 1,7-2,7 cm compr.; poucos tricomas glandulares no eixo foliar e tricomas plumosos às vezes presentes e esparsos na inflorescência. Inflorescência em panícula terminal curta, imersa na folhagem ou apenas ligeiramente exserta, racemos individuais ascendentes, ca. $4,8 \mathrm{~cm}$ compr., botões +ou- corimbosos no ápice; brácteas 2,54 x 1,5-3 mm, oval-lanceoladas, agudas a acuminadas. Flores ca. 1,5 mm compr., articuladas logo abaixo do hipanto; sépala abaxial 7-8 mm compr.; pétalas suborbiculares a sub-retangulares, amarelo-ouro, pétala vexilar com máculas avermelhadas, pétalas laterais 9-12 x 7-8 mm; filetes pubescentes na base, $10-14 \mathrm{~mm}$ compr. Legume 7,5-8,5 x 1,7-2,2 cm, oblongo a oblongolanceolado, plano, fortemente compresso apiculado; valvas lenhosas, esparsamente pubérulas.

Material examinado: BRASIL: Paraíba: Puxinanã, Afloramento II, 13/III/2011, fl., fr., S.A.L. Silva 04 (ACAM).

Distribuição geográfica: Nordeste (Piauí, Ceará, Rio Grande do Norte, Paraíba, Pernambuco, Bahia) (LEWIS, 2011). Aparentemente, é uma espécie endêmica da Caatinga, encontrada, principalmente, nas formas mais abertas, em altitudes de 150 a 600 m (QUEIROZ, 2009).

Poincianella gardneriana é espécie assemelhada morfologicamente a P. bracteosa (Tul.) L.P. Queiroz, da qual se diferencia pelas folhas, geralmente com menor número de pinas (6-10 em $P$. gardneriana vs. 5-13 em P. bracteosa), folíolos menores (14-27 x 11-22 mm em P. gardneriana vs. 23-55 x 15-40 mm em P. bracteosa) e menos numerosos (ca. de 2-4 pares em $P$. gardneriana vs. ca. de 3-5 pares por pina em $P$. bracteosa), além das 
flores e brácteas também menores (flores 1,5 cm diâm. e brácteas 2,5-4 x 1,5-3 mm em $P$. gardneriana vs. flores 2,5 cm diâm. e brácteas 8-12 x 5-7 mm em P. bracteosa).

5. Senna martiana (Benth.) H.S.Irwim \& Barneby, Mem. New York Bot. Gard. 35: 465. 1982.

Figura 3F

Arbusto a arvoreta, 1-4 m alt.; ramos velutinos, ramificação aberta a candelabriforme. Folhas pinadas; folíolos cartáceos, 17-23 pares, decrescentes em cada extremidade da raque, oblíquamente oblongos, ápice agudo e mucronado, densa e discretamente pubérulos e reticulados nas duas faces; nervura principal excêntrica, nervuras secundárias salientes nas duas faces; estípulas 7-18 × 3-5 mm, lanceoladas, acuminadas, dilatadas a auriculadas no lado oposto ao folíolo, quase amplexicaules, base alaranjada, secretora; pecíolo 20 $33 \mathrm{~mm}$ compr.; raque $24-30 \mathrm{~mm}$ compr.; segmentos interfoliares 8-24 mm compr.; nectários ausentes. Inflorescências em racemos axilares, robustos, eretos ou curvados para cima, 10-45 cm compr.; brácteas 1,8-2,3 x 1,5-1,9 cm, petaloides, amarelas, côncavas, recobrindo o botão e formando um cone no ápice do racemo. Flores ca. $5 \mathrm{~cm}$ diâm., sépalas 10-15 mm compr., pétalas 1,8-2,4 x 1,3-1,6 cm, amarelas, obovais, a vexilar ligeiramente diferenciada, flabelada; pedicelo 1-1,5 cm compr. Legume 8-11 x 1,3-2 cm, plano-compresso, patente, linear-oblongo, não alado; estípite ca. 7-10 mm compr.; valvas papiráceas, nigrescentes.

Material examinado: BRASIL: Paraíba: Puxinanã, Afloramento I, 05/IX/2011, fl., fr., S.A.L. Silva 05 (ACAM).

Esta espécie é endêmica da Caatinga (QUEIROZ, 2009).

Distribuição geográfica: Nordeste (Piauí, Ceará, Rio Grande do Norte, Paraíba, Pernambuco, Bahia, Alagoas) (SOUZA; BORTOLUZZI, 2011b).

Senna martiana assemelha-se morfologicamente à Senna alata (L.) Roxb., mas pode ser facilmente diagnosticada pelos folíolos mais numerosos, 17 a 23 pares, relativamente mais estreitos, 1,1-1,8 cme com indumento mais denso nas duas faces foliares.

6. Senna obstusifolia (L.) H.S.Irwin \& Barneby, Mem. New York Bot. Gard. 35: 252. 1982.
Erva a subarbusto, 0,5-1 $\mathrm{m}$ alt.; ramos glabros a esparsamente pilosos. Folhas membranáceas, 3 pares de folíolos, fortemente acrescentes distalmente, os distais 4,5-5 x 2-2,5 cm, 1,9-2, 1x mais longos que largos, largamente obovais, ápice arredondado e mucronado, base cuneada, face adaxial glabra, face abaxial glabra ou com tricomas adpressos esparsos; nervura principal central e nervuras secundárias pouco proeminentes; estípulas lineares, $10-15$ × $2 \mathrm{~mm}$; pecíolo $25-35 \mathrm{~mm}$ compr.; raque 2-2,6 cm compr.; segmentos interfoliares 14-18 mm compr.; nectários fusiformes, estipitados, localizados entre o primeiro e, geralmente, o segundo par de folíolos. Inflorescências em racemos axilares, 1-3 (-4) flores; pedúnculo 1-5 mm compr. Flores ca. 1,5 cm diâm., botões globosos, deflexos; sépalas internas 6-9 mm compr., obovais, ca. 1,5x maiores do que as externas; pétalas oblongo-obovais a vexilar mais larga, amarelo pálidas; pedicelo 9-15 mm compr. Legume 10-13 x 0,2$0,3 \mathrm{~cm}$, estreitamente linear (quase filiforme), arqueado, ligeiramente compresso, em seção transversal levemente hexagonal; estípite ca. $3 \mathrm{~mm}$ compr.; valvas papiráceas.

Material examinado: BRASIL: Paraíba: Puxinanã, Afloramento I, 05/IX/2011, fl., fr., J.C.B. Brasileiro et al. 103 (ACAM); Afloramento II, 05/IX/2011, fl., S.A.L. Silva s.n. (ACAM).

Distribuição geográfica: Norte (Roraima, Pará, Amazonas, Tocantins, Acre), Nordeste (Maranhão, Piauí, Ceará, Rio Grande do Norte, Paraíba, Pernambuco, Bahia, Alagoas), Centro-Oeste (Mato Grosso, Goiás, Distrito Federal, Mato Grosso do Sul), Sudeste (Minas Gerais, São Paulo, Rio de Janeiro), Sul (Paraná) (SOUZA; BORTOLUZZI, 2011b). No domínio da Caatinga é comumente encontrada em ambientes degradados em margens de rios e lagos, em altitudes de até $1000 \mathrm{~m}$.

Senna obtusifolia assemelha-se morfologicamente, especialmente com relação ao hábito, comportamento anual e flores relativamente pequenas, à espécie Senna uniflora (Mill.) H.S.Irwin \& Barneby, da qual pode ser facilmente diferenciada pela ausência de tricomas longos e ferrugíneos nos ramos e pelos frutos com valvas planas.

7. Senna rizzinii H.S.Irwin \& Barneby, Mem. New York Bot. Gard. 35: 174. 1982. 
Arbusto, 0,8-1,5 m alt.; ramos jovens vilosos, tricomas acinzentados, longos e retorcidos. Folhas cartáceas a coriáceas, 2 pares de folíolos, pubescentes, acrescentes distalmente, os distais 3,4-4,8 x 1,3-2,2 cm, 2-3x mais longos que largos, elípticos, assimétricos na base, agudos a obtusos, face adaxial pubérula, face abaxial vilosa; nervura principal excêntrica na base, nervuras secundárias broquidódromas, geralmente inconspícuas; estípulas setiformes, ca. 3-6 mm compr.; margem concolor; pecíolo 13-21 mm compr.; nectário clavado curtamente estipitado localizado entre o $1^{\circ}$ par de folíolos. Inflorescências em racemos axilares, ligeiramente corimbosos, 2,5-6,5 cm compr.; brácteas suborbiculares, 2-6 x 2-6 mm, geralmente persistentes até a frutificação. Flores ca. 3,5 cm diâm., botões globosos; sépalas verde-amareladas, as maiores internas, ca. $18 \mathrm{~mm}$ compr.; pétalas obovais, 1,4-1,8 x 0,7-0,9 $\mathrm{cm}$, amarelo-alaranjadas; estames 7 , ápice das anteras com divisão que resulta em uma abertura de 2 poros; pedicelo 1-2,5 cm compr. Legume ca. 4,8 x 1,2-1,8 cm, cilíndrico, carnoso, base contraída em estípite com ca. 3-5 mm compr., pubescente, nigrescente na maturação.

Material examinado: BRASIL: Paraíba: Puxinanã, Afloramento II, 24/X/2010, fl., S.A.L. Silva 07 (ACAM).

Distribuição geográfica: Nordeste (Maranhão, Piauí, Ceará, Rio Grande do Norte, Paraíba, Pernambuco, Bahia, Alagoas, Sergipe) (SOUZA; BORTOLUZZI, 2011b).

Restringe-se à Caatinga, distribuída do sul do Ceará e Paraíba até a região central do Estado da Bahia, a leste do rio São Francisco sendo mais frequentemente encontrada sobre solo arenoso, em altitudes de 400 a 900 m (QUEIROZ, 2009).

Senna rizzini pode ser diferenciada das demais espécies congêneres da área estudada pelo hábito arbustivo, ramos enegrecidos, folíolos e frutos pubescentes, além das brácteas suborbiculares geralmente persistentes nos frutos.

8. Senna splendida (Vogel) H.S.Irwin \& Barneby, Mem. New York Bot. Gard. 35: 190. 1982.

Arbusto a arvoreta, 1,5-4 m alt.; ramos glabros, quando jovens fractiflexos. Folhas papiráceas, 2 pares de folíolos, glaucos, acrescentes distalmente, os distais
4,6-8,2 x 1,7-3 cm, 8x mais longos do que largos, estreitamente elípticos, simétricos na base, obtusos, glabros; nervura principal mediana, nervuras secundárias braquidódromas, reticuladas na face abaxial; margem discolor; estípulas caducas, ca. 18-20 mm compr., linear-oblanceoladas; pecíolo 29-30 mm compr.; raque 5-17 mm compr.; nectário clavado, discretamente estipitado, localizado entre o primeiro par de folíolos. Inflorescências em racemos axilares em ramos distais, às vezes agrupados em panículas terminais, corimbosas a umbeliformes. Flores ca. 6-7 cm diâm., botões globosos no ápice, inteiros ou apiculados; sépalas verdes, as maiores internas, ca. 10-30 mm compr.; pétalas amarelas, obovais a vexilar flabeladas; 7 estames, os 3 abaxiais ca. $3 \mathrm{x}$ maiores do que os 4 centrais, anteras cujo ápice apresenta uma divisão que resulta numa abertura em 2 poros; pedicelo ca. 1,6-2,8 cm compr. Legume ca. 17-22 x 0,5-0,8 cm, cilíndrico, carnoso com base contraída em estípite de ca. $7 \mathrm{~mm}$ compr.; pericarpo glabro, verdeescuro na maturação.

Material examinado: BRASIL: Paraíba: Puxinanã, Afloramento II, 19/IX/2010, fl., S.A.L. Silva 08 (ACAM).

Distribuição geográfica: Nordeste (Piauí, Ceará, Rio Grande do Norte, Paraíba, Pernambuco, Bahia, Alagoas, Sergipe), Centro-Oeste (Mato Grosso do Sul), Sudeste (Minas Gerais, Espírito Santo, São Paulo), Sul (Paraná) (SOUZA; BORTOLUZZI, 2011b). Na Caatinga, ocorre principalmente associada à mesorregião do Agreste, nas formas arbóreas transicionais entre a floresta litorânea e as áreas mais secas do interior, e em matas ciliares dentro do domínio da Caatinga.

Senna splendida é assemelhada morfologicamente a Senna macranthera var. pudibunda (Benth.) H.S.Irwin \& Barneby, da qual diferencia-se por apresentar folíolos glabros de base simétrica.

\section{Senna sp.}

Arbusto, 1-3 m alt.; ramos inermes. Folhas pilosas, 2 pares de folíolos, acrescentes distalmente, os distais 2,5-3,4 x 1,3-1,4 cm, estreitamente arredondados com ápice cuneado, pubescentes; estípulas linear-lanceoladas, 3 mm compr.; pecíolo 13-15 mm compr.; raque 22-24 mm compr.; nectário pateliforme, localizado no primeiro 
FIGURA 3: Espécies de Leguminosae de afloramentos rochosos de Puxinanã, PB: A. Vista parcial do afloramento I; B. Aspecto do afloramento II, evidenciando populações de Leguminosae; C. Chamaescrista rotundifolia; D. Macroptilium lathyroides; E. Mimosa paraibana; F. Senna martiana; G. Zornia miryadena; H. Mimosa sensitiva.

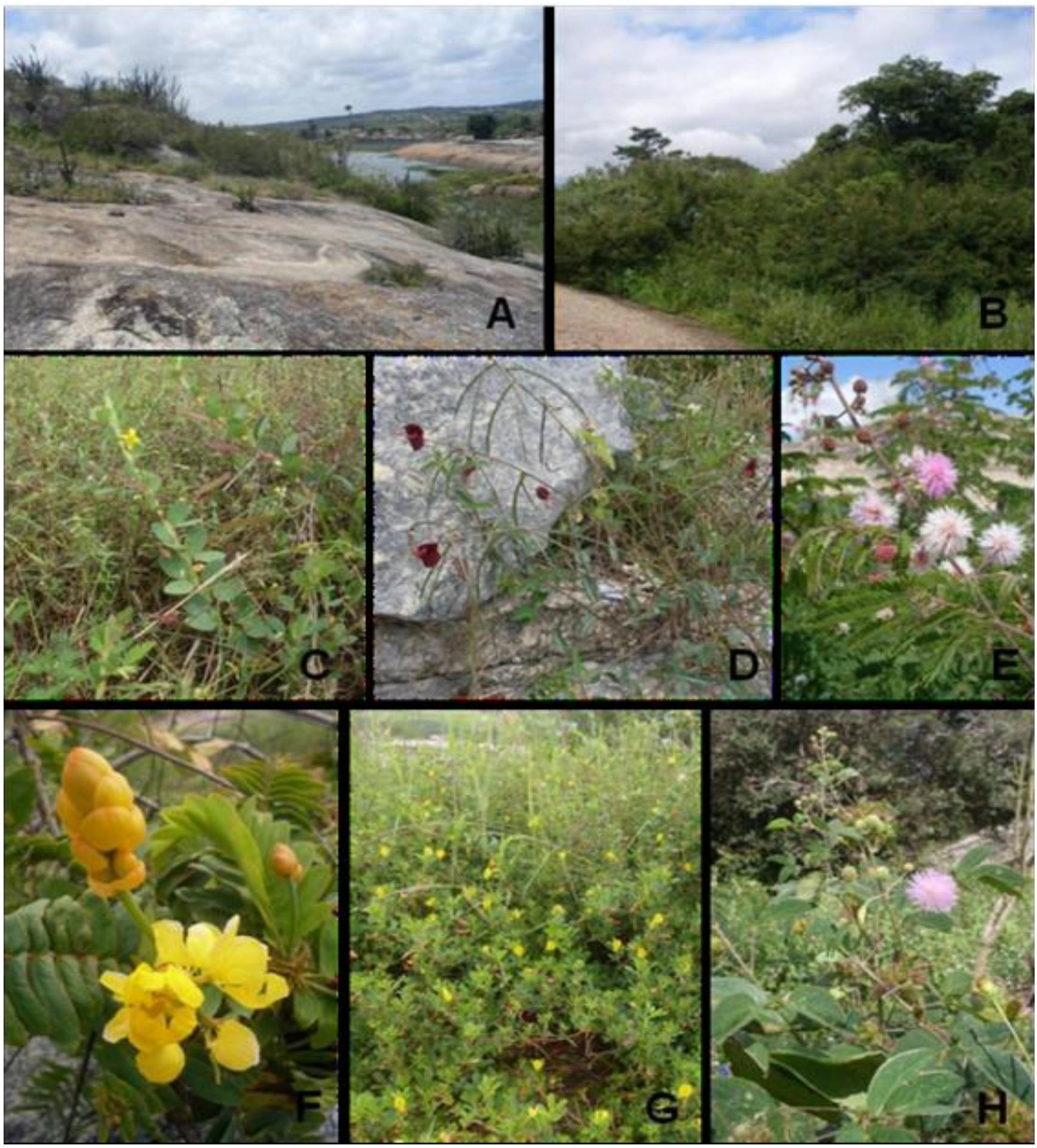


par de folíolos. Inflorescências em racemos axilares em ramos distais. Flores ca. 1,5 cm diâm., botões globosos no ápice; sépalas amareladas com base enegrecida, ca. 5-7-5-8 mm compr.; pétalas amarelas, obovais, 1-1,2 x 0,8-1 cm; estames 7, anteras contraídas no ápice em um bico biporoso; pedicelo 1-1,4 cm compr. Legume ca. 2-2,5 x 0,3-0,5 cm, cilíndrico, pêndulo, ligeiramente curvo, piloso, estípite ca. $4 \mathrm{~mm}$ compr.

Material examinado: BRASIL: Paraíba: Puxinanã, Afloramento II, 05/IX/2010, fl., S.A.L. Silva 11 (ACAM).

\section{Chave para as espécies da subfamília Mimosoideae}

1. Árvores ou subarbustos

2. Nectário extrafloral discoide, séssil, localizado próximo à metade do pecíolo; fruto legume 16. Pithecellobium dulce

2. Nectário extrafloral ausente; fruto craspédio

3. Flores diplostêmones; glomérulos axilares; fruto linear, subséssil, plano-compresso, reto, artículos quadrangulares

11. Mimosa misera

3. Flores isostêmones; glomérulos axilares ou agrupados em pseudoracemos terminais; fruto oblongo, séssil, plano-compresso, artículos retangulares 14. Mimosa sensitiva

1. Arbustos

4. Flores diplostêmones; nectários extraflorais ausentes

5. Inflorescências em glomérulos agrupados em pseudoracemos terminais; corola creme; fruto legume 15. Mimosa sp.

5. Inflorescências em glomérulos axilares; corola rosa; fruto craspédio

6. Craspédio oblongo, plano-compresso, reto; estípulas estreitamente lanceoladas ... 12. Mimosa paraibana

6. Craspédio linear, plano-compresso, reto ou ligeiramente curvo; estípulas ovais 13..............Mimosa pigra

4. Flores polistêmones; nectários extraflorais presentes

7. Nectário estipitado, discoide; fruto linear, espiralado, falcado, valvas carnosas

10. Chloroleucon dumosum

7. Nectário séssil; fruto legume, oblongo a oblongolinear, valvas onduladas lateralmente
8. Nectário pateliforme, elíptico, localizado no terço inferior do pecíolo; valvas rígido-coriáceas ......... 18. Senegalia ricoae

8. Nectário nunca pateliforme nem localizado no terço inferior do pecíolo

9. Nectário crateriforme ou caliciforme, localizado próximo à metade do pecíolo; valvas glabras 17. Senegalia polyphylla

9. Nectário crateriforme, localizado na base ou no ápice do pecíolo; valvas pubescentes-puberulentas a glabrescentes. 19. Senegalia tenuifolia

10. Chloroleucon dumosum (Benth.) G.P.Lewis, Legumes of Bahia: 165. 1987.

Árvore ou arbusto, até $5 \mathrm{~m}$ alt.; ramos diferenciados em ramos com comprimento alternados em longos e curtos. Folhas bipinadas; estípulas caducas; espículas interpinais ausentes; parafilídios ausentes; nectários estipitados, discoides, geralmente localizados abaixo ou próximo do meio do pecíolo. Inflorescências em glomérulos axilares, isolados ou fasciculados; homomórficos ou heteromórficos. Legume linear geralmente espiralado até falcado, deiscente; valvas papiráceas ou indeiscentes ou valvas carnosas.

Material examinado: BRASIL: Paraíba: Puxinanã, Afloramento II, 27/II/2011, fr., S.A.L. Silva 10 (ACAM).

Esta espécie é endêmica do Brasil (QUEIROZ, 2009).

Distribuição geográfica: Nordeste (Ceará, Rio Grande do Norte, Paraíba, Pernambuco, Alagoas, Sergipe, Bahia), Centro-Oeste (Distrito Federal), Sudeste (Minas Gerais, Rio de Janeiro).

Segundo Queiroz (2009), Chloroleucon é um gênero relativamente pequeno, com cerca de dez espécies, que ocorrem em ambientes xéricos do semiárido brasileiro. Chloroleucon dumosum caracteriza-se morfologicamente por apresentar nectário estipitado, discoide, e pelo fruto linear, espiralado, falcado, com valvas carnosas.

11. Mimosa misera Benth., J. Bot. (Hooker) 4: 411. 1842.

Subarbusto prostrado a decumbente; ramos inermes ou pouco aculeados; tricomas glandulares peduculados presentes pelo menos na raque foliar. Folhas 
5-11, divaricadas; pinas decrescentes proximalmente, folíolos aproximadamente do mesmo tamanho, os medianos 2-5 x 0,7-2 mm, ápice arredondado, nervura principal subcentral, inconspícua; parafilídios ausentes; espículas interpinais ausentes; estípulas ovais persistentes; nectários extraflorais ausentes. Inflorescências em glomérulos axilares, globosos, 5-6 mm diâm, pedunculados. Flores rosa, trímeras; diplostêmones; corola infundibiliforme, lacínias eretas; anteras globosas, estames 6 , conectivo não apiculado. Craspédio 15-30 x 4-5 mm, linear subséssil, planocompresso, reto, inerme; artículos quadrangulares, ca. $3 \times 3 \mathrm{~mm}$.

Material examinado: BRASIL: Paraíba: Puxinanã, Afloramento II, 19/IX/2010, fl., fr., S.A.L. Silva 09 (ACAM).

Esta espécie é endêmica da Caatinga (QUEIROZ, 2009).

Distribuição geográfica: Nordeste (Piauí, Ceará, Paraíba e Bahia).

É uma espécie que ocorre principalmente em locais de solo arenoso em Caatinga, em altitudes de 400 a 800 $\mathrm{m}$, com poucos registros para campos rupestres, em altitudes mais elevadas (QUEIROZ, 2009). É endêmica do Brasil, da Caatinga, e sua distribuição geográfica abrange os estados do Piauí, Ceará e Bahia (DUTRA; MORIM, 2010), sendo aqui registrada pela primeira vez para o estado da Paraíba.

Mimosa misera é uma espécie que apresenta número e tamanho de pinas, cobertura por tricomas e presença de acúleos extremamente variáveis e apresenta uma afinidade com Mimosa cordistipula Benth., da qual se diferencia por apresentar folhas divaricadas e ápice das pinas não espinescente.

12. Mimosa paraibana Barneby, Mem. New York Bot. Gard. 65: 171. 1991.

Figura 3E

Arbusto a árvore, até $9 \mathrm{~m}$ alt.; ramos armados com acúleos pequenos, recurvados, geralmente também presentes na face adaxial do pecíolo e da raque foliar. Folhas 8-15 (pinas distais), pinas acrescentes distalmente; folíolos acrescentes para o ápice, os distais 5-9 x 2-4 mm, oblongo-obovais, os distais com ápice mucronado, arredondado, obovais, base obliquamente truncada; 3-nérveos, nervura principal excêntrica, ramificada; estípulas estreitamente lanceoladas, persistentes; espículas interpinais curtas; nectários extraflorais ausentes. Inflorescências em glomérulos axilares nos ramos distais ou agrupados em pseudoracemos curtos e terminais, globosos a elípticos, 5-6 mm diâm., 1-2 fasciculados, pedunculados. Flores rosa, tetrâmeras; diplostêmones; cálice campanulado, curtamente denticulado; corola infundibiliforme, lacínias eretas; anteras globosas, estames 8 , conectivo não apiculado. Craspédio 43-65 x 19-20 mm, oblongo, plano-compresso, reto, curtamente estipitado; valvas nigrescentes, cartáceas; artículos retangulares, 5,6 x 18-19 mm; margens espessadas.

Material examinado: BRASIL: Paraíba: Puxinanã, Afloramento I, 03/VII/2011, fl., S.A.L. Silva 12 (ACAM); Afloramento II, 03/VII/2011, fr., J.S. Rodrigues 102 (ACAM).

Esta espécie é endêmica da Região Nordeste do Brasil (BARNEBY, 1991).

Distribuição geográfica: Do Maranhão ao Ceará e, para o sul, até o norte de Pernambuco. Ocorre em Caatinga e florestas estacionais, sobre solos arenosos e pedregosos (QUEIROZ, 2009) e em Mata Atlântica (DUTRA; MORIM, 2010).

Mimosa paraibana caracteriza-se, principalmente, pelos folíolos obovais, relativamente largos, e pelos frutos oblongos com artículos do craspédio glabros, nigrescentes e nítidos.

\section{Mimosa pigra L., Cent. Pl. I: 13. 1755.}

Arbusto, às vezes escandente, 1-3 m alt.; indumento híspido ou escabro constituído por tricomas rígidos de base larga, pálidos ou amarelados, ramos armados com acúleos retos ou recurvados. Folhas 27-40 (pinas distais), pinas equilongas ou as basais ligeiramente menores, folíolos decrescentes proximal e distalmente, os medianos 5-9 x 0,7-1 mm, lineares, ápice obtuso, base obliquamente cordada; 4-5-nérveos, nervuras paralelas, salientes e discolores na face abaxial, nervura principal subcentral; estípulas ovais persistentes; 
espículas interpinais longas, subuladas, eretas; nectários extraflorais ausentes. Inflorescências em glomérulos axilares ou agrupados em pseudoracemos curtos e terminais, globosos a elípticos, 7-9 mm diâm., 1-2 fasciculados, pedunculados. Flores rosa, tetrâmeras; diplostêmones; cálice paleáceo com tubo curto e 4 lobos longos e setosos; corola infundibiliforme, lacínias eretas, estriadas; anteras globosas, estames 8, conectivo não apiculado. Craspédio 60-73 x 8-14 mm, linear, planocompresso, curtamente estipitado, reto ou ligeiramente curvo; artículos retangulares, 3-4 x 11-12 mm; margens espessadas, retas; valvas cartáceas, densamente híspidosetosas.

Material examinado: BRASIL: Paraíba: Puxinanã, Afloramento I, 27/II/2010, fl., S.A.L. Silva 13 (ACAM).

Distribuição geográfica: Norte (Amazonas, Acre), Nordeste (Paraíba, Bahia), Centro-oeste (Mato Grosso, Goiás e Distrito Federal), Sudeste (Minas Gerais), Sul (Santa Catarina) (DUTRA; MORIM, 2010). Neste trabalho, o estado da Paraíba é acrescentado à sua distribuição geográfica. Apenas uma de suas variedades pode ser encontrada na Caatinga, embora seja uma planta pioneira em localidades onde há maior disponibilidade de água (QUEIROZ, 2009).

Mimosa pigra é facilmente reconhecida pelo indumento híspido constituído por tricomas rígidos, adpressos e de base larga que revestem os ramos, folhas, frutos e pelas nervuras discolores na face abaxial.

14. Mimosa sensitiva L., Sp. Pl.: 518. 1753.

Figura $3 \mathrm{H}$

Subarbusto prostrado ou escandente; ramos angulosos, costados, armados com série longitudinais de acúleos fortemente recurvados sobre as costelas, continuando sobre o pecíolo. Folhas compostas; folíolos em 2 pares, o par proximal com o folíolo interno atrofiado, folíolos distais geralmente maiores, 25-45 x 13-21 mm, ovais a elípticos, ligeiramente falcados, ápice acuminado, base hemicordada; 5-nérveos, nervuras palmadas, proeminentes, reticuladas, nervura principal excêntrica; estípulas ovais a lanceoladas, persistentes; espícula interpinal presente; parafilídios subulados; nectários extraflorais ausentes. Inflorescências em glomérulos globosos axilares nas folhas distais ou agrupados em pseudoracemos curtos, terminais, 6-8 mm diâm., 1-2 fasciculados, pedunculados. Flores rosa, tetrâmeras; isostêmones; cálice paleáceo, com lacínias longas e divididas em setas rígidas; corola cilíndrica, lacínias eretas, incurvadas; anteras globosas, estames 4 , conectivo não apiculado. Craspédio 15-25 x 5-7 mm, oblongo, plano-compresso, séssil; artículos retangulares, ca. 4 × $6 \mathrm{~mm}$; margens espessadas, sinuosas, cobertas por setas longas e rígidas.

Material examinado: BRASIL: Paraíba: Puxinanã, Afloramento I, 19/IX/2010, fl., S.A.L. Silva 14 (ACAM); Afloramento II, 19/IX/2010, fl., fr., J.S. Rodrigues 74 (ACAM).

Distribuição geográfica: Norte (Pará, Amazonas), Nordeste (Maranhão, Piauí, Ceará, Paraíba, Pernambuco, Bahia), Centro-oeste (Mato Grosso do Sul), Sudeste (Minas Gerais) (DUTRA; MORIM, 2012).

$\mathrm{Na}$ Caatinga, ocorre uma variedade (Mimosa sensitiva var. sensitiva) como planta pioneira em ambientes antropizados, de 120 a $700 \mathrm{~m}$ alt. (QUEIROZ, 2009). Neste trabalho, o estado da Paraíba é acrescentado à distribuição geográfica da espécie.

Mimosa sensitiva é facilmente reconhecida por apresentar apenas um par de pinas, sendo o folíolo interno do par basal atrofiado, bem como pelas séries longitudinais de acúleos recurvados nos ramos.

\section{Mimosa sp.}

Arbusto, até $6 \mathrm{~m}$ alt.; ramos inermes. Folhas com 8-10 pinas, decrescentes distalmente; folíolos decrescentes para o ápice, 1-2 x 3-5 mm, oblongo, ápice agudo, base arredondada; estípulas espinescentes; nectários extraflorais ausentes. Inflorescências em glomérulos agrupados em pseudoracemos terminais, globosos, 30 mm diâm., 2-3 fasciculados. Flores creme, tetrâmeras; diplostêmones; estames 8. Legume 75-90 x 20-25 mm, oblongo, plano-compresso, deiscente, ápice falcado, margem saliente.

Material examinado: BRASIL: Paraíba: Puxinanã, Afloramento I, 24/X/2010, fl., S.A.L. Silva 30 (ACAM). 
16. Pithecellobium dulce Benth., Lond. J. Bot. 3: 199. 1844.

Árvore ou arbusto, 15-20 m alt.; ramos delgados. Folhas bipinadas, com uma juga, cada pina com um par de foliólulos, 0,9-32 x 0,6-10 mm; nectário extrafloral discoide, séssil, localizado próximo à metade do pecíolo. Inflorescências em glomérulos, panículas pêndulas. Flores 1-1,5 cm diâm., actinomorfas, brancoamareladas. Legume $20 \mathrm{~cm} \times 10-15 \mathrm{~mm}$, enroscado, tomentoso, deiscente.

Material examinado: BRASIL: Paraíba: Puxinanã, Afloramento II, 13/III/2011, fl., S.A.L. Silva 16 (ACAM).

Distribuição geográfica: Nordeste (Piauí, Ceará, Rio Grande do Norte, Paraíba, Pernambuco, Bahia, Alagoas, Sergipe), Sudeste (São Paulo, Rio de Janeiro) (IGANCI, 2011).

Pode ser facilmente reconhecida pelas folhas bipinadas, com um par de jugas, flores em capítulos globosos e pelos frutos retorcidos e curvos.

17. Senegalia polyphylla (DC.) Britton \& Rose in Britton \& Killip, Ann. New York Acad. Sci. xxxv. (Mimos. \& Caelsap. Colomb.) 142. 1936.

Arbusto ou arvoreta, 2-5 m alt.; ramos armados com acúleos de base larga, retos ou curvados para cima, raramente presentes também no lado inferior do pecíolo e raque foliar. Folhas com (19-)28-32 pinas estas opostas, as distais 4,5-8 cm compr.; folíolos cartáceos, os medianos (-6)10-14 x (1,8)3-4 mm, oblongos, obtusos, base truncada, 3-4-nérveos; estípulas caducas, 6-9 mm compr.; nectário crateriforme ou caliciforme, séssil, localizado próximo ao meio do pecíolo; pecíolo 25-40 mm compr. Inflorescências em glomérulos hemisféricos, fascículos agrupados em panículas ou pseudoracemos terminais; ca. 7-8 $\mathrm{mm}$ diâm, pedúnculo 5-7 mm compr., 2-5 fasciculados. Flores ca. $5 \mathrm{~mm}$ compr.; polistêmones; cálice campanulado, corola infundibiliforme, densamente pubescente; tricomas brancos estipitados; estames brancos; ovário densamente pubescente. Legume 10,5-22 x 2,5-3 cm, oblongo, ápice arredondado, base contraída em estípite de 10-15 mm compr.; valvas glabras, castanhas, discretamente onduladas lateralmente.
Material examinado: BRASIL: Paraíba: Puxinanã, Afloramento II, 27/II/2011, fl., S.A.L. Silva 17 (ACAM).

Distribuição geográfica: Norte (Pará, Amazonas), Nordeste (Maranhão, Piauí, Ceará, Paraíba, Bahia, Alagoas, Sergipe), Centro-Oeste (Mato Grosso, Goiás, Distrito Federal, Mato Grosso do Sul), Sudeste (Minas Gerais, Espírito Santo, São Paulo, Rio de Janeiro), Sul (Paraná) (MORIM; BARROS, 2011). Na Caatinga, é mais associada às formações arbóreas e matas ciliares em rios temporários, em altitudes de 450 a 900 m, sobre solo argilo-arenoso (QUEIROZ, 2009).

Senegalia polyphylla é bastante assemelhada a Senegalia riparia (Kunth) Britton \& Rose in Britton \& Killip, e diferencia-se desta, principalmente, pela inflorescência paniculada e pelo maior número de pinas e folíolos.

18. Senegalia ricoae (Bocage \& Miotto) L.P.Queiroz, Legum. Caatinga: 202. 2009.

Arbusto a arvoreta, 2-5 m alt.; ramos com acúleos recurvos. Folhas com 33-41 pinas opostas, ligeiramente decrescentes para as extremidades; folíolos cartáceos, glabros, ligeiramente decrescentes para as extremidades da pina, os medianos 4-6 x 1-1,3 mm, oblongo-lineares, planos, base assimétrica, oblíqua; nervura principal excêntrica; estípulas 6-7 x $2 \mathrm{~mm}$; pecíolo 10-15 mm compr.; nectário séssil, pateliforme, elíptico, localizado no terço inferior do pecíolo. Inflorescências em glomérulos, 2-4 fasciculados, fascículos axilares, 7-10 mm diâm., pedunculados, pedúnculo $10-20 \mathrm{~mm}$ compr. Flores ca. $6 \mathrm{~mm}$ compr., polistêmones; cálice campanulado; corola cilíndrica, pubérula, lacínias eretas; estames brancos. Legume ca. 9 x 2 cm, oblongo-linear, plano, apiculado, reto, margens retas; valvas rígido-coriáceas, enegrecidas, lateralmente onduladas.

Material examinado: BRASIL: Paraíba: Puxinanã, Afloramento II, 27/II/2011, fl., S.A.L. Silva 18(ACAM).

Senegalia ricoae é endêmica da Caatinga (QUEIROZ, 2009).

Distribuição geográfica: Nordeste (Bahia, Paraíba) (MORIM; BARROS, 2011). Neste trabalho é referida pela primeira vez para o estado da Paraíba. 
Esta espécie assemelha-se morfologicamente a Senegalia tenuifolia Britton \& Rose, da qual se diferenciapelos glomérulos agrupados em panículas terminais, enquanto $S$. Ricoae possui seus glomérulos em fascículos axilares. Da mesma forma que se diferencia da $S$. Polyphylla pela corola (infundibiliformeem $S$. polyphylla vs. cilíndrica em S. ricoae) e por seu fruto (ápice arredondado em $S$. polyphylla vs. ápice apiculado em S. ricoae).

19. Senegalia tenuifolia Britton \& Rose, N. Amer. Fl. 23(2): 118. 128. 1928.

Arbusto a árvore, ca. $12 \mathrm{~m}$ alt.; às vezes com ramos delgados e pendentes; ramos claros, acinzentados, discretamente estriados longitudinalmente, acúleos recurvados, esparsamente dispostos, acúleos geralmente presentes no lado inferior do pecíolo e raque foliar. Folhas com 20-52 pinas, 9,5-24 cm compr., pinas opostas, as distais 2,5-4,5(-9,5) cm compr., ascendentes, folíolos cartáceos, os medianos 2,5-7 x 0,5-0,8(-1) mm, lineares, ligeiramente falcados, imbricados, agudos, base oblíqua; 1-nervados; estípulas caducas, ca. 4 × 2 mm; pecíolo 10-18(-50) mm compr.; nectário crateriforme, séssil, localizado da base ao ápice do pecíolo. Inflorescências em glomérulos globosos, 1-2 fasciculados, fascículos agrupados em panículas terminais, ca. 4-5 mm diâm., pedúnculo 5-10 mm compr. Flores ca. 4-5 mm compr., polistêmones; cálice campanulado, densamente pubérulo; corola infundibiliforme; estames brancos; ovário densamente pubescente ou apenas na metade superior, apresentando tricomas brancos. Legume 10-18 x 2,1-4 cm, oblongo ou oblongo-linear, ápice arredondado a obtuso, apiculado; valvas pubescentes-puberulentas a glabrescentes, onduladas lateralmente; semente com pleurograma apical-basal.

Material examinado: BRASIL: Paraíba: Puxinanã, Afloramento II, 27/II/2011, fl., S.A.L. Silva 19 (ACAM).

Distribuição geográfica: Norte (Pará, Amazonas, Acre), Nordeste (Paraíba, Pernambuco, Bahia), CentroOeste (Mato Grosso, Goiás), Sudeste (Minas Gerais, São Paulo, Rio de Janeiro), Sul (Paraná, Santa Catarina) (MORIM; BARROS, 2011). No Nordeste, ocorre principalmente em florestas pluviais e em florestas estacionais, ocasionalmente na Caatinga, especialmente em Caatinga arbórea, de 400 a 900 m alt. (QUEIROZ, 2009).

No que se refere às espécies de Senegalia registradas para a Caatinga, $S$. tenuifolia pode ser reconhecida pelas folhas multijugas (10 a 18 pares de pinas), geralmente $2 \mathrm{x}$ mais longas do que largas, pelo número elevado de folíolos por pina (20 a 52 pares) e pelas flores e folíolos relativamente pequenos.

\section{Chave para as espécies da subfamília Papilionoideae}

1. Arbustos ou subarbustos

2. Arbustos, folhas digitado-trifolioladas; fruto legume 23. Crotalaria bahiensis

2. Subarbustos, folhas paripinadas, com 15 a 35 pares de folíolos; fruto lomento

20. Aeschynomene evenia

1. Ervas, trepadeiras herbáceas ou lianas

3. Ervas

4. Folhas compostas digitadas, com 4 folíolos

29. Zornia myriadena

4. Folhas pinadas, trifolioladas

5. Fascículo de brácteas na extremidade distal do pedúnculo 27. Macroptilium lathyroides

5. Fascículo de brácteas próximo à base do pedúnculo 26. Macroptilium bracteatum

3. Trepadeiras herbáceas ou lianas

6. Estípulas elípticas, dilatadas na base; flores ressupinadas 22. Canavalia brasiliensis

6. Estípulas subuladas, oblongas ou peltadas; flores não ressupinadas

7. Estípulas subuladas, caducas; flores com pétalas azuladas 21. Calopogonium caeruleum

7. Estípulas oblongas a peltadas; flores com pétalas lilases a rosas

8. Estípulas oblongas; flores com carena torcida em $270^{\circ}$ 28. Vigna peduncularis

8. Estípulas peltadas, caducas; flores com carena encurvada ca. $90^{\circ}$

9. Face abaxial dos folíolos glabrescente

25. Dioclea violacea 
9. Face abaxial dos folíolos e valvas dos frutos com indumento tomentoso e canescente

24. Dioclea grandiflora

20. Aeschynomene evenia C. Wright in Sauvalle, Anales Acad. Ci. Med. Habana 5: 334-335. 1868.

Subarbusto ereto, virgado, ca. $1 \mathrm{~m}$ alt.; ramos glabros, com tricomas esparsos de base larga. Folhas paripinadas, 15-35 pares de folíolos; estípulas peltadas, caducas e lanceoladas; pecíolo 3-5 mm compr.; raque 18-27 mm compr. Inflorescências em racemos axilares, 2-4 flores, pedúnculo mais longo que a folha adjacente. Flores ca. $7 \mathrm{~mm}$ compr., cálice bilabiado, campanulado, ca. $2 \mathrm{~mm}$ compr., glabro, lábio superior curtamente 2-denteado, lábio inferior curtamente 3-denteado; pétalas amarelas, estandarte glabro, suborbicular, ca. $6 \times 6 \mathrm{~mm}$. Lomento10-14 artículos quadrados, 2,5-3 mm diâm., retos, dilatados sobre a semente; estípite com ca. $3 \mathrm{~mm}$ compr.

Material examinado: BRASIL: Paraíba: Puxinanã, Afloramento I, 22/VIII/2011, fl., fr., S.A.L. Silva 20 (ACAM).

Distribuição geográfica: Norte (Pará), Nordeste (Maranhão, Paraíba), Sudeste (Minas Gerais, Rio de Janeiro), Sul (Paraná) (LIMA, 2011). Na Caatinga, está associada a ambientes antropizados e brejosos (QUEIROZ, 2009). Neste trabalho está sendo referida pela primeira vez para o estado da Paraíba.

Caracteriza-se, principalmente, pelo estandarte com ca. $6 \mathrm{~mm}$ compr. e estípite com 3-4 mm compr.

21. Calopogonium caeruleum (Benth.) Hemsl., Biol. Cent. -Amer., Bot. 1(4): 301. 1880.

Trepadeira volúvel; ramos jovens pubérulos a seríceos. Folhas trifolioladas; folíolos cartáceos a coriáceos, folíolo terminal 5,7-8,1 x 3,2 -3,5 cm, largamente oval a subromboidal, ápice obtuso, base truncada, folíolos laterais fortemente assimétricos, face adaxial pubérula a serícea, abaxial serícea a velutina; estípulas subuladas, caducas, pecíolo 3-4,5 cm compr.; raque 1,1-1,5 cm compr. Inflorescência em pseudoracemos axilares e terminais. Flores 2-3, fasciculadas, ca. $10 \mathrm{~mm}$ compr., não ressupinadas, bractéolas na base do cálice; cálice 3-5 mm compr., piloso, tubo cilíndrico, lacínias lanceoladas, pétalas azuladas, glabras, estandarte em posição superior em relação às demais pétalas, $8-10 \times 6,8 \mathrm{~mm}$, glabro, alas obovais; estames-10, diadelfos $(9+1)$; ovário séssil. Legume 5-5,5 x 0,7-0,8 cm, linear, fortemente compresso, internamente septado entre as sementes.

Material examinado: BRASIL: Paraíba: Puxinanã, Afloramento II, 24/VIII/2011, fl., fr., S.A.L. Silva 21 (ACAM).

Distribuição geográfica: Norte (Roraima, Pará, Acre), Nordeste (Maranhão, Piauí, Ceará, Paraíba, Bahia), Centro-Oeste (Mato Grosso, Goiás, Distrito Federal), Sudeste (Minas Gerais, Rio de Janeiro), Sul (Paraná) (LIMA, 2011). Na Caatinga, ocorre principalmente em locais antropizados e próximo a riachos temporários, de 440-550 $\mathrm{m}$ alt. (QUEIROZ, 2009).

É uma espécie comumente confundida com espécies de Galactia P. Browne, podendo ser diferenciada pela inflorescência mais robusta, com flores congestas, pelo tubo do cálice cilíndrico em Calopogonium e campanulado em Galactia, pelas pétalas azuladas e pela superfície sulcada entre as sementes das valvas dos frutos.

22. Canavalia brasiliensis Mart. ex Benth., Comm. Leg. Gen.: 71. 1837.

Trepadeira volúvel; ramos jovens, pecíolo, raque e eixo da inflorescência pubescentes. Folhas trifolioladas; folíolos membranáceos a cartáceos, esparsa a densamente pubescentes nas duas faces, folíolo terminal 4,5-10 × 3,5-6 cm, elíptico a oval, ápice agudo a obtuso, base obtusa, margem pilosa, folíolos laterais ligeiramente assimétricos; estípulas 1-4 mm compr., elípticas, dilatadas na base; pecíolo 15-60 mm compr.; raque 13-25 mm compr. Inflorescências em pseudoracemos de 5,5-7,5 cm compr. Flores de 20-33 mm compr., ressupinadas, cálice externamente glabrescente, cilíndrico-campanulado, lábio superior inteiro com ápice arredondado ou obtuso, lábio inferior tridentado, lacínia inferior mais longa do que as duas laterais $(0,6 \mathrm{~mm}$ da lacínia inferior $v s .0,3 \mathrm{~mm}$ da lacínia lateral); pétalas rosa a lilás, estandarte em posição inferior em relação às demais pétalas, base amarela ou 
branca e estrias claras em direção ao ápice. Legume 6-10 x 1-1,5 cm, valvas lenhosas e pubescentes.

Material examinado: BRASIL: Paraíba: Puxinanã, Afloramento II, 19/IX/2010, fl., fr., S.A.L. Silva 22 (ACAM).

Distribuição geográfica: Norte (Pará, Acre), Nordeste (Piauí, Ceará, Rio Grande do Norte, Paraíba, Pernambuco, Bahia), Centro-Oeste (Goiás), Sudeste (Rio de Janeiro) (QUEIROZ, 2011). Esta espécie é frequentemente encontrada em áreas de Caatinga, ocorrendo principalmente em áreas antropizadas na Bahia e Pernambuco sobre solos argilosos ou arenoargilosos, de 280 a $600 \mathrm{~m}$ alt. (QUEIROZ, 2009).

Canavalia brasiliensis pode ser facilmente reconhecida pelas flores ressupinadas e pelos legumes com margens aladas.

23. Crotalaria bahiensis Windler \& S.G.Skinner, Phytologia 50: 187. 1982.

Subarbusto 0,7-1 m alt.; ramos jovens, pecíolo e raques da inflorescência lanosos, tricomas longos, densos e ferrugíneos. Folhas digitado-trifolioladas, folíolos cartáceos, 43-55 x 31-40 mm, mais longos que o pecíolo, suborbiculares, ápice arredondado, faces adaxial e abaxial vilosas; estípulas subuladas, ca. $2 \mathrm{~mm}$ compr.; pecíolo ca. $20 \mathrm{~mm}$ compr. Inflorescências em racemos terminais, eixo robusto, lenhoso, 8-12 cm compr. Flores ca. $17 \mathrm{~mm}$ compr., cálice campanulado, ca. $5 \mathrm{~mm}$ compr., viloso, lacínias 7-8 mm compr., lanceoladas, livres no ápice; estandarte suborbicular; pedicelo 1-2 mm compr.; estames concrescidos em tubo, 8-9 mm compr. Legume 12-15 x 7 mm compr., oblongo, ca. 2x mais longo que largo; valvas pubérulas, tricomas adpressos, translúcidos.

Material examinado: BRASIL: Paraíba: Puxinanã, Afloramento I, 19/IX/2010, fl., S.A.L. Silva 23 (ACAM); Afloramento II, 13/III/2011, S.A.L. Silva 39 (ACAM).

Esta espécie é endêmica da Região Nordeste do Brasil (QUEIROZ, 2009).

Distribuição geográfica: Nordeste (Bahia e Paraíba) (FLORES, 2010). Ocorre na Caatinga,
Cerrado e Campos rupestres, em altitudes de 7001000 m (QUEIROZ, 2009). A espécie é facilmente reconhecida pelos folíolos orbiculares, vilosos, e pelo indumento ferrugíneo tornando-se enegrecido quando herborizado.

24. Dioclea grandiflora Mart. ex Benth., Comm. Leg. Gen. 68. 1837.

Liana, caule com ca. $5 \mathrm{~cm}$ diâm.; ramos jovens, pecíolo, raque, face abaxial dos folíolos e valvas dos frutos com indumento tomentoso e canescente e raques da inflorescência vilosa, com tricomas eretos, retos, densos, macios e canescentes. Folhas trifolioladas; folíolos papiráceos, o terminal 70-95 x 55-70 mm, largamente obovais a suborbiculares, ápice arredondado a pouco obtuso, base arredondada, os laterais obovais, assimétricos, ligeiramente menores; nervuras salientes na face abaxial; estípulas peltadas, ca. 5 × $2 \mathrm{~mm}$, caducas; estipelas setiformes, ca. $4 \mathrm{~mm}$ compr.; pecíolo 60-80 mm compr.; raque 12-18 mm compr. Inflorescências em pseudoracemos pedunculados, terminais, secundifloros, 0,5-1 m compr., florido mais de $2 / 3$ do seu comprimento. Flores 25-28 mm compr., não ressupinadas, cálice vináceo, externamente pubescente, tubo campanulado 8-9 mm compr., lacínia superior emarginada; pétalas roxas, unguículo 4-7 mm compr., estandarte largamente oboval, glabro, com área bicalosa e amarela próximo à base, alas obliquamente oblongas, peças da carena triangulares terminando em rostro truncado, carena encurvada ca. $90^{\circ}$; anteras dimórficas; ovário séssil, estigma dilatado. Legume 9-14 x $4 \mathrm{~cm}$, oblongo, compresso, margem superior arqueada, margem inferior sinuosa; valvas lenhosas, vilosas, canescentes.

Material examinado: BRASIL: Paraíba: Puxinanã, Afloramento I, 19/IX/2010, fl., S.A.L. Silva 24 (ACAM); Afloramento II, 27/II/2011, fr., J.S. Rodrigues 96 (ACAM).

Esta espécie é endêmica da Caatinga (QUEIROZ, 2009).

Distribuição geográfica: Nordeste (Piauí, Ceará, Rio Grande do Norte, Paraíba, Pernambuco, Bahia, Alagoas, Sergipe) (QUEIROZ, 2010). A espécie Dioclea grandiflora diferencia-se de $D$. violacea pelo indumento 
canescente e pelo endorcarpo aderido à semente, além da inflorescência axilar em $D$. violacea .

25. Dioclea violacea Mart. ex Benth., Comm. Leg. Gen.: 69. 1837.

Liana, caule com até $10 \mathrm{~cm}$ diâm.; ramos jovens, pecíolo, raque e eixo da inflorescência híspidos a glabrescentes, tricomas eretos, firmes, ferrugíneos e longos. Folhas trifolioladas; folíolos papiráceos, o terminal 75-105 x 56-87 mm, suborbiculares, ápice arredondado, discretamente acuminado, base arredondada ligeiramente cordada; estípulas peltadas, 5-7 x 2-3 mm, caducas; estipelas setiformes, 4-8 mm compr.; pecíolo $60-75 \mathrm{~mm}$ compr.; raque $6-11 \mathrm{~mm}$ compr. Inflorescências em pseudoracemos axilares, pedunculados e secundifloros, 0,4-1 m compr., pedicelo 3-5 mm compr. Flores ca. $20 \mathrm{~mm}$ compr., não ressupinadas, cálice ferrugíneo, externamente pubescente, tubo campanulado 8-10 mm compr., lacínia superior emarginada, pétalas roxas; estandarte em posição superior em relação às demais pétalas, largamente oboval, glabro, com área bicalosa amarela a esverdeada próximo à base, alas obliquamente oblongas, peças da carena triangulares terminando em um rostro truncado, carena encurvada; anteras dimórficas; ovário séssil, estilete dilatado. Legume 13-15 x 4,5-5,6 cm, oblongo, valvas lenhosas, híspidas, tricomas ferrugíneos.

Material examinado: BRASIL: Paraíba: Puxinanã, Afloramento I, 19/IX/2010, fl., S.A.L. Silva 25 (ACAM); Afloramento II, 13/III/2011, fl., fr., S.A.L. Silva 38 (ACAM).

Distribuição geográfica: Nordeste (Paraíba, Piauí, Pernambuco, Bahia, Sergipe), Centro-Oeste (Mato Grosso do Sul), Sudeste (Minas Gerais, Espírito Santo, São Paulo, Rio de Janeiro), Sul (Paraná, Santa Catarina, Rio Grande do Sul) (QUEIROZ, 2010). Na Caatinga, foi registrada principalmente em florestas estacionais do Ceará até o norte de Minas Gerais (QUEIROZ, 2009). Nesse trabalho o estado da Paraíba é acrescentado à distribuição geográfica da espécie.

26. Macroptilium bracteatum (Nees \& Mart.) Maréchal \& Baudet, Bull. Jard. Bot. Natl. Belg. 44: 443. 1974.
Erva prostrada ou escandente, ramos jovens, pecíolo e eixo da inflorescência vilosos, tricomas longos, eretos e acinzentados. Folhas trifolioladas, folíolos papiráceos a cartáceos, o terminal 25-55 x 20-37 mm, ovais a romboidais, às vezes lobados na $1 / 2$ inferior, ápice agudo a obtuso e mucronado, vilosos nas duas faces; pecíolo 18-45 mm compr.; raque 5-10 $\mathrm{mm}$ compr. Inflorescências em pseudoracemos, 10-15 cm compr.; fascículo de brácteas lanceoladas a lineares a ca. 4-10 $\mathrm{mm}$ compr. presente próximo à base do pedúnculo. Flores 25-28 mm compr.; cálice externamente pubérulo a viloso, tubo cilíndrico, 4-5 x 1,8-2 mm; lacínias triangulares, mais curtas do que o tubo, 1,5-2 mm compr.; estandarte creme rosado, 12-18 x 8-11 mm; alas atropurpúreas, quase pretas, 20-25 x 11-13 mm; pedicelo 2-3 mm compr. Legume 6,5-8 x 0,5-0,6 cm, linear, ligeiramente compresso, reto, patente, valvas coriáceas, esparsamente vilosas a híspidas, com tricomas adpressos ou patentes.

Material examinado: BRASIL: Paraíba: Puxinanã, Afloramento I, 19/IX/2010, fl., fr., S.A.L. Silva 26 (ACAM).

Distribuição geográfica: Nordeste (Piauí, Ceará, Paraíba, Pernambuco, Bahia), Centro-Oeste (Mato Grosso do Sul), Sudeste (Minas Gerais, São Paulo, Rio de Janeiro) (MOURA, 2011). Na área da Caatinga, ocorre principalmente em plantações abandonadas e margens de rios temporários, sobre solo arenoso, de 3000 a 700 m alt. (QUEIROZ, 2009).

Pode ser facilmente diferenciada das demais espécies do gênero, pela presença de um fascículo de brácteas próximo à base do pedúnculo da inflorescência.

27. Macroptilium lathyroides (L.) Urb., Symb. Antill. 9(4): 457. 1928.

Figura 3D

Subarbusto ou erva, 0,7-1,5 $\mathrm{m}$ alt.; ramificado na base, ramos longos e virgados. Folhas trifolioladas, folíolos papiráceos, o terminal 40-53 x 14-24 mm, três vezes mais longos do que largos, oblongo lineares com base dilatada, ápice agudo a obtuso, glabros ou com a face abaxial com tricomas adpressos e esparsos; pecíolo 26-40 mm compr., glabrescente; raque 10-12 mm compr. Inflorescências em pseudoracemos, 10- 
$30 \mathrm{~cm}$ compr.; fascículo de brácteas na extremidade distal do pedúnculo. Flores 20-25 mm compr.; cálice externamente glabrescente, com tricomas adpressos muito esparsos, tubo cilíndrico, 3-4 x 1,5 mm; lacínias triangulares, mais curtas do que o tubo, 1,5-2 mm compr.; estandarte creme com ápice róseo, alas atropurpúreas, carena rósea; pedicelo 1-2 mm compr. Legume 6,5-8 x 0,5-0,6 cm, linear, cilíndrico, reto, patente; valvas coriáceas, glabrescentes, com tricomas adpressos e esparsos.

Material examinado: BRASIL: Paraíba: Puxinanã, Afloramento I, 19/IX/2010, fl., fr., S.A.L. Silva 27 (ACAM).

Distribuição geográfica: Norte (Roraima, Pará, Amazonas), Nordeste (Maranhão, Piauí, Ceará, Paraíba, Pernambuco, Bahia, Alagoas), Centro-Oeste (Mato Grosso, Goiás, Distrito Federal, Mato Grosso do Sul), Sudeste (Minas Gerais, Espírito Santo, São Paulo, Rio de Janeiro), Sul (Paraná) (MOURA, 2011). Na Caatinga vegeta em solo arenoso (QUEIROZ, 2009).

Macroptilium lathyroides diferencia-se das demais espécies do gênero por apresentar um conjunto de brácteas na extremidade distal da inflorescência.

28. Vigna peduncularis (Kunth) Fawc. \& Rendle, Fl. Jamaica 4: 68. 1920.

Trepadeira volúvel ou erva decumbente, ca. 45 $\mathrm{cm}$ alt.; ramos volúveis no ápice; pecíolo, raque e eixo da inflorescência glabrescentes. Folhas trifolioladas; folíolos papiráceos, o terminal 40-85 x 22-65 mm, ovais, subdeltoides ou subromboides, ápice agudo, base obtusa, os laterais assimétricos, face adaxial glabra, face abaxial esparsamente pubescente a glabrescente; estípulas oblongas, 4-5 mm compr.; pecíolo 25-50 mm compr.; raque 11-20 mm compr. Inflorescências em pseudoracemos axilares, 23-26 mm compr., nodosos, concentrados próximo ao ápice da inflorescência. Flores 11-16 mm compr., não ressupinadas, cálice campanulado, tubo 3-4 cm compr., esparsamente pubescente, lacínias ca. 1,5 $\mathrm{mm}$ compr.; pétalas lilases a róseas; estandarte suborbicular, 10-12 x 8-12 mm, carena espiraladamente torcida ca. 270 graus, mais escura do que as demais pétalas; pedicelo até $1 \mathrm{~mm}$ compr. ou ausente. Legume 7,5-10 x 0,3-0,4 cm; valvas esparsamente pubescentes.

Material examinado: BRASIL: Paraíba: Puxinanã, Afloramento I, 05/IX/2010, fl., fr., S.A.L. Silva 28 (ACAM); Afloramento II, 05/II/2010, fl., fr., J.S. Rodrigues 54 (ACAM).

Distribuição geográfica: Norte (Roraima, Pará, Amazonas), Nordeste (Bahia, Paraíba), Centro-Oeste (Mato Grosso, Goiás, Distrito Federal, Mato Grosso do Sul), Sudeste (Minas Gerais, São Paulo), Sul (Paraná, Rio Grande do Sul) (PEREZ, 2011a). Ocorre em ambientes antropizados, de 200 a $650 \mathrm{~m}$ alt. (QUEIROZ, 2009). Neste trabalho é referida pela primeira vez para o estado da Paraíba.

Vigna peduncularis é facilmente reconhecida pelas flores com carenas torcidas em 270 graus e concentradas no ápice da inflorescência.

29. Zornia myriadena Benth. In Mart., Fl. Bras. 15 (1): 85. 1859.

Figura $3 \mathrm{G}$

Erva prostrada a decumbente; ramificada desde a base, com tricomas curtos e brancos. Folhas compostas digitadas, com 4 folíolos acrescentes, os distais 8-22 x 4-6 mm, 7x mais longos do que largos, obovais, espatulados, ápice arredondado a emarginado, base cuneada, glabros a esparsamente pubérulos e pontuados nas duas faces; uninérvios, nervura principal central; estípulas peltadas, linear-lanceoladas; pecíolo pubérulo, 2-6 mm compr. Flores isoladas, axilares, 10-12 mm compr., cálice glabro, cilíndrico-campanulado, ca. 5 mm compr., 4-laciniado, lacínia superior 2-dentada, lacínia inferior mais longa que as demais; pétalas amarelas, glabras; estandarte suborbicular, ca. 10×10 mm. Lomento 9-15-articulado, artículos discretamente retangulares, ca. 2 x 1,2 mm, glabros, não reticulados, não cerdosos.

Material examinado: BRASIL: Paraíba: Puxinanã, Afloramento I, 19/IX/2010, fl., fr., S.A.L. Silva 29 (ACAM); Afloramento II, 19/IX/2010, fl., J.C.B. Brasileiro et al. 84 (ACAM).

Distribuição geográfica: Nordeste (Paraíba, Pernambuco, Alagoas, Bahia), Sudeste (Minas Gerais) 
(PEREZ, 2009; 2011b). Encontrada na Caatinga sobre solo arenoso e, comumente, como uma planta colonizadora em áreas degradadas, em altitudes de 250 a 900 m (QUEIROZ, 2009). É também conhecida nos cerrados e campos rupestres do Brasil (PEREZ, 2009). Neste trabalho está sendo referida pela primeira vez para o estado da Paraíba.

Devido à presença de flores solitárias, Z. myriadena se assemelha com $Z$. echinocarpa Benth., mas difere desta por possuir artículos do lomento sem acúleos, com tricomas estrelados e muitas glândulas. Pode ser observada plasticidade morfológica quanto ao hábito e quanto à coloração nos ramos de $Z$ myriadena; em ambientes abertos os ramos tendem a ser prostrados e avermelhados, enquanto que em ambientes de sombra, ou fechados, eles tendem a ser eretos e não avermelhados (PEREZ, 2009).

\section{Agradecimentos}

À Universidade Estadual da Paraíba (UEPB) pela infra-estrutura para realização deste trabalho. A primeira autora agradece à Juliana Castelo Branco Brasileiro e Juliana de Sales Rodrigues, pelo auxílio durante as coletas de material e a esta última pela hospedagem no município de Puxinanã, PB. J.I.M. Melo agradece ao $\mathrm{CNPq}$ (Conselho Nacional de Desenvolvimento Científico e Tecnológico) pela Bolsa de Produtividade em Pesquisa (Proc. n. 302751/2012-2).

\section{Referências}

AESA - AGÊNCIA EXECUTIVA DE GESTÃO DAS ÁGUAS DO ESTADO DA PARAIIBA. Boletim de informações climáticas. 2006. Disponível em: <http://www.aesa.pb.gov.br>. Acesso em: 21 fev. 2013.

ALMEIDA, A.; FELIX, W. J. P.; ANDRADE, L. A.; FÉLIX, L. P. Leguminosae na flora de inselbergues do Estado da Paraíba, Nordeste do Brasil. Revista Brasileira de Biociências, Porto Alegre, v. 5, supl. 2, p. 750-752, 2007.

ANGIOSPERM PHYLOGENY GROUP. An update of the Angiosperm Phylogeny Group classification for the orders and families of flowering plants: APG II. Botanical Journal of the Linnean Society, Londres, v. 141, p. 399-506, 2003.

BARNEBY, R. C. Sensitivae Censitae, a description of the genus Mimosa L. (Mimosaceae) in the New World. Memoirs of the New York Botanical Garden, New York, v. 65, p. 1-835, 1991.
BARROS, M. J. F. Senegalia Raf. (Leguminosae, Mimosoideae) do Domínio Atlântico, Brasil. 2011. 138 f. Dissertação (Mestrado em Botânica) - Instituto de Pesquisas Jardim Botânico do Rio de Janeiro, Rio de Janeiro. 2011.

BRASIL - MINISTÉRIO DAS MINAS E ENERGIA. SECRETARIA DE GEOLOGIA, MINERAÇÃO E TRANSFORMAÇÃO MINERAL. Projeto cadastro de fontes de abastecimento por água subterrânea: diagnóstico do município de Puxinanã. Recife: CPRM, 2005. 20 p.

CARDOSO, D. B. O. S.; QUEIROZ, L. P. Leguminosae das caatingas do Tucano. Rodriguésia, Rio de Janeiro, v. 58, n. 2, p. 379-391, 2007. 20 p.

CÓRDULA, E.; QUEIROZ, L. P.; ALVES, M. Leguminosae. In ALVES, M.; M. F.; MACIEL, J. R.; MARTINS, S. (Org.). Flora de Mirandiba. Vol. 1. Recife: Associação de Plantas do Nordeste, 2009. p. 183-233.

DAMBROS, V. S.; EISINGER, S. M.; CANTO-DOROW, T. S. Leguminosae do Campus da Universidade Federal de Santa Maria, Santa Maria, RS, Brasil. Ciência e Natura, Santa Maria, v. 26, n. 2, p. 43-60, 2004

DUTRA, V. F.; MORIM, M. P. Lista de espécies da flora do Brasil - Mimosa. 2010. Disponível em: $<$ http://floradobrasil.jbrj. gov.br/2010/FB018826>. Acesso em: 26 set. 2011.

FERREIRA, G. C.; HOPKINS, M. J. G.; SECCO, R. S Contribuição ao conhecimento morfológico das espécies de Leguminosae comercializadas no estado do Pará, como "angelim". Acta Amazonica, Manaus, v. 34, n. 2, p. 219-232, 2004.

FORZZA, R. C.; LEITMAN, P. M.; COSTA, A.; CARVALHO JR., A. A.; PEIXOTO, A. L.; WALTER, B. M. T.; BICUDO, C.; ZAPPI, D.; COSTA, D. P.; LLERAS, E.; MARTINELLI, G.; LIMA, H. C.; PRADO, J.; STEHMANN, J. R.; BAUMGRATZ, J. F. A.; PIRANI, J. R.; SYLVESTRE, L. S.; MAIA, L. C.; LOHMANN, L. G.; PAGANUCCI, L.; SILVEIRA, M.; NADRUZ, M.; MAMEDE, M. C. H.; BASTOS, M. N. C.; MORIM, M. P.; BARBOSA, M. R.; MENEZES, M.; HOPKINS, M.; SECCO, R.; CAVALCANTI, T.; SOUZA, V. C. Lista de espécies da flora do Brasil. 2011. Disponível em: <http://www.tropicos.org/>. Acesso em: 17 out. 2011.

FLORES, A. S. Lista de espécies da flora do Brasil - Crotalaria. 2010. Disponível em: <http://floradobrasil.jbrj.gov.br/2010/ FB018452>. Acesso em: 26 set. 2011.

FRANCINO, D. M. T. Anatomia foliar de espécies de Chamaecrista Moench. (Leguminosae/Caesalpinioideae) ocorrentes em campo rupestre. 72 f. Dissertação (Mestrado em Botânica) - Universidade Federal de Viçosa, Viçosa. 2006.

IGANCI, J. R. V. Lista de espécies da flora do Brasil Pithecellobium. 2011. Disponível em: <http://floradobrasil.jbrj. gov.br/2011/FB083609>. Acesso em: 16 out. 2011.

JUDD, W. S.; CAMPBELL, C. S.; KELLOGG, E. A.; STEVENS, P. Plant Systematics: a phylogenetic approach. Sunderland: Sinauer Associates, 1999. 620 p.

LEWIS, G. P. Lista de espécies da flora do Brasil - Poincianella 2011. Disponível em: <http://floradobrasil.jbrj.gov.br/2011/ FB109775>. Acesso em: 16 out. 2011.

LEWIS, G. P.; SCHRIRE, B.; MACKINDER, B.; LOCK, M. Legumes of the World. London: Royal Botanic Gardens Kew, $2005.577 \mathrm{p}$. 
LIMA, H. C. Lista de espécies da flora do Brasil - Calopogonium. 2011. Disponível em: <http://floradobrasil.jbrj.gov.br/2011/ FB022852>. Acesso em: 16 out. 2011.

MARACAJÁ, P. B.; BATISTA, C. H. F.; SOUSA, A. H.; VASCONCELOS, W. E. Levantamento florístico e fitosociológico do extrato arbustivo-arbóreo de dois ambientes na Vila Santa Catarina, Serra do Mel, RN. Revista de Biologia e Ciências da Terra, Campina Grande, v. 3, n. 2, p. 20-33, 2003.

MARACAJÁ, V. P. B. B.; SIMÕES, G. F. M.; DINIZ FILHO, E. T.; SILVA, P. S.; OLIVEIRA, A. M. O potencial ecoturístico do município de Puxinanã, Paraíba, Brasil. Revista Verde de Agroecologia e Desenvolvimento Sustentável, Mossoró, v. 1, p. 26-40, 2006.

MORIM, M. P.; BARROS, M. J. F. Lista de espécies da flora do Brasil -Senegalia. 2011. Disponível em: <http://floradobrasil.jbrj. gov.br/2011/FB101015>. Acesso em: 16 out. 2011.

MOURA, T. M. Lista de espécies da flora do Brasil Macroptilium. 2011. Disponível em: <http://floradobrasil.jbrj.gov. br/2011/FB029790>. Acesso em: 16 out. 2011.

PEREZ, A. P. F. O gênero Zornia J.F.Gmel. (Leguminosae, Papilionoideae, Dalbergieae): revisão taxonômica das espécies ocorrentes no Brasil e filogenia. 2009. $284 \mathrm{f}$. Tese (Doutorado em Botânica) - Universidade Estadual de Campinas, Campinas. 2009.

PEREZ, A. P. F. Lista de espécies da flora do Brasil - Vigna. 2011a. Disponível em: <http://floradobrasil.jbrj.gov.br/2011/ FB029910>. Acesso em: 16 out. 2011.

PEREZ, A. P. F. Lista de espécies da flora do Brasil - Zornia. 2011b. Disponível em: <http://floradobrasil.jbrj.gov.br/2011/ FB019264>. Acesso em: 28 out. 2011.

PIRES, L. C.; SARTORI, A. L. B.; POTT, V. J. Aeschynomene (Leguminosae, Papilionoideae, Aeschynomeneae) no Estado de Mato Grosso do Sul, Brasil. Hoehnea, São Paulo, v. 33, n. 4, p. 419-453, 2006.

POREMBSKI, S.; MARTINELLI, G.; OHLEMÜLLER, R.; BARTHLOTT, W. Diversity and ecology of saxicolous vegetation mats on inselbergs in the Brazilian Atlantic rainforest. Diversity and Distributions, Austin, v. 4, p. 107-119, 1998.

QUEIROZ, L. P. Leguminosas da Caatinga. Feira de Santana: Universidade Estadual de Feira de Santana, 2009. 443 p.

QUEIROZ, L. P. Lista de espécies da flora do Brasil - Dioclea. 2010. Disponível em: <http://floradobrasil.jbrj.gov.br/2010/ FB083108>. Acesso em: 26 set. 2011.

QUEIROZ, L. P. Lista de espécies da flora do Brasil - Canavalia. 2011. Disponível em: <http://floradobrasil.jbrj.gov.br/2011/ FB022855>. Acesso em: 16 out. 2011.
RIBEIRO, G. N.; TEOTIA, H. S. Estudo dos solos e uso atual da terra no Agreste paraibano (região de Puxinanã), através de sensoriamento remoto e geoprocessamento. Revista Brasileira de Gestão Ambiental, Mossoró, v. 1, n. 1, p. 46-52, 2007.

RIBEIRO, G. N.; TEOTIA, H. S.; MARACAJÁ, V. P. B. B.; BARROS, D. F. Mapeamento do uso da terra e cobertura vegetal no Agreste paraibano: municípios de Pocinhos e Puxinanã. Revista Caatinga, Mossoró, v. 21, n. 2, p. 231-244, 2008.

RODRIGUES, R. S.; FLORES, A. S.; MIOTTO, S. T. S.; BAPTISTA, L. R. M. O gênero Senna (Leguminosae, Caesalpinioideae) no Rio Grande do Sul, Brasil. Acta Botanica Brasilica, São Paulo, v. 19, n. 1, p. 1-16, 2005.

SAVASSI-COUTINHO, A. P. Revisão taxonômica e estudos filogenéticos de Mimosa L. sect. Calothamnos Barneby (Leguminosae - Mimosoideae). 2009. 320 f. Tese (Doutorado em Botânica) - Universidade de São Paulo, São Paulo. 2009.

SILVA, J. S.; SALES, M. F. O gênero Mimosa (LeguminosaeMimosoideae) na Microrregião do Vale do Ipanema, Pernambuco. Rodriguésia, Rio de Janeiro, v. 59, n. 3, p. 435-448, 2008.

SOUZA, V. C.; BORTOLUZZI, R. L. C. Lista de espécies da flora do Brasil - Chamaecrista. 2011a. Disponível em: $<$ http:// floradobrasil.jbrj.gov.br/2011/FB082925>. Acesso em: 16 out. 2011.

SOUZA, V. C.; BORTOLUZZI, R. L. C. Lista de espécies da flora do Brasil - Senna. 2011b. Disponível em: <http://floradobrasil.jbrj. gov.br/2011/FB019079>. Acesso em: 16 out. 2011.

THE INTERNATIONAL PLANT NAMES INDEX - IPNI 2012. Disponível em: <http://www.ipni.org/>. Acesso em: 21 fev. 2013.

TÖLKE, E. E. A. D.; SILVA, J. B.; PEREIRA, A. R. L.; MELO, J. I. M. Flora vascular de um inselbergue no estado da Paraíba, Nordeste do Brasil. Biotemas, Florianópolis, v. 24, n. 4, p. 39-48, 2011.

VAZ, A. M. S. F. Lista de espécies da flora do Brasil - Bauhinia. 2011. Disponível em: <http://floradobrasil.jbrj.gov.br/2011/ FB082659>. Acesso em: 16 out. 2011.

VAZ, A. M. S. F.; TOZZI, A. M. G. A. Bauhinia ser. Cansenia (Leguminosae: Caesalpinioideae) no Brasil. Rodriguésia, Rio de Janeiro, v. 54, n. 83, p. 55-143, 2003.

$\mathrm{W}^{3}$ TROPICOS. Tropicos home - Missouri Botanical Garden VAST (Vascular Tropicos). 2010. Disponível em: <http://www. tropicos.org/>. Acesso em: 25 nov. 2011. 